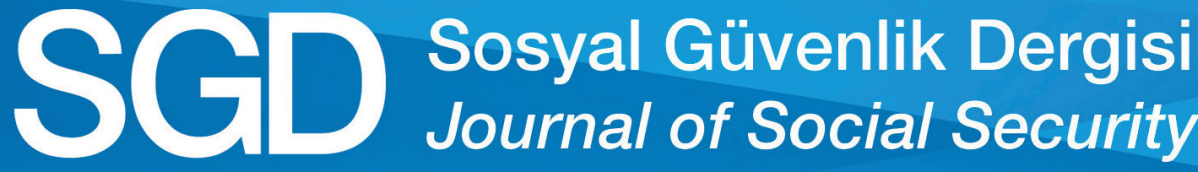 \\ P-ISSN: 2146-4839 \\ E-ISSN: 2148-483X
}

\section{Ĕ̆itim-İstihdam ve Eğitim-Gelir Etkinliği: Yükseköğretime Katılımın OECD Ülkeleri Bazında Panel Veri Analizi}

\section{Education-Employment and Education-Income Effectiveness: \\ Panel Data Analysis of the Participation in Higher Education Based on OECD Countries}

\section{Fatma YEŞİLKAYA}

Mersin Üniversitesi, İktisadi ve İdari Bilimler Fakültesi,

Çalışma Ekonomisi Endüstri İlişkileri Bölümü

\section{Türker TOPALHAN}

Ankara Hacı Bayram Veli Üniversitesi, İktisadi ve İdari Bilimler Fakültesi,

Çalıșma Ekonomisi Endüstri İlișkileri Bölümü

\section{Sezin ÜNAL MIÇOOĞULLARI}

Ankara Hacı Bayram Veli Üniversitesi, İktisadi ve İdari Bilimler Fakültesi,

Çalışma Ekonomisi Endüstri İlişkileri Bölümü

Aralık 2020, Cilt 10, Say1 2, Sayfa 413-430

December 2020, Volume 10, Issue 2, Page

413-430

P-ISSN: $2146-4839$

E-ISSN: $2148-483 \mathrm{X}$

$2020-2$

e-posta: sgd@sgk.gov.tr

Yazılar yayınlanmak üzere kabul edildiği takdirde, SGD elektronik ortamda tam metin olarak yayımlamak da dahil olmak üzere, tüm yayın haklarına sahip olacaktır. Yayınlanan yazılardaki görüşlerin sorumluluğu yazarlarına aittir. Yazı ve tablolardan kaynak gösterilerek alıntı yapılabilir.

If the manuscripts are accepted to be published, the SGD has the possession of right of publicationand the copyright of the manuscripts, included publishing the whole text in the digital area. Articles published in the journal represent solely the views of the authors.

Some parts of the articles and the tables can be citeded by showing the source. 


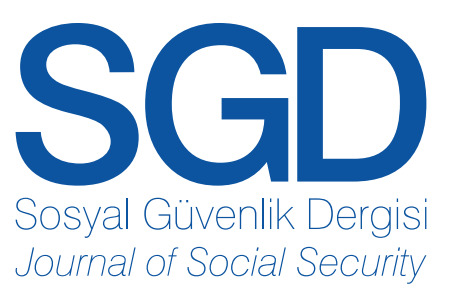

Cilt: 10 - Say1: 2 - Y11: 2020

Volume: 10 - Issue: 2 - Year: 2020

P-ISSN: 2146-4839

E-ISSN: 2148-483X

Sahibi / Owner of the Journal

Sosyal Güvenlik Kurumu Adına / On behalf of the Social Security Institution

İsmail YILMAZ

(Kurum Başkanı / President of the Institution)

Sorumlu Yazı İşleri Müdürü / Responsible Publication Manager

Uğur KORKMAZ

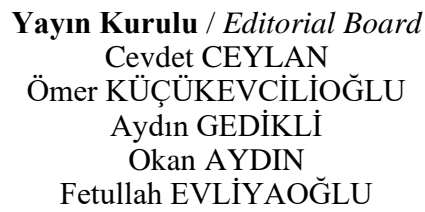

Editörler / Editors

Doç. Dr. Erdem CAM

Selda DEMİR

Redaksiyon / Redaction

Nihan ERTÜRK

Yayın Türü: Uluslararası Süreli Yayın / Type of Publication: International Periodical

Yayın Aralığı: 6 aylık / Frequency of Publication: Twice a Year

Dili: Türkçe ve İngilizce / Language: Turkish and English

Basım Tarihi / Press Date: 20.12.2020

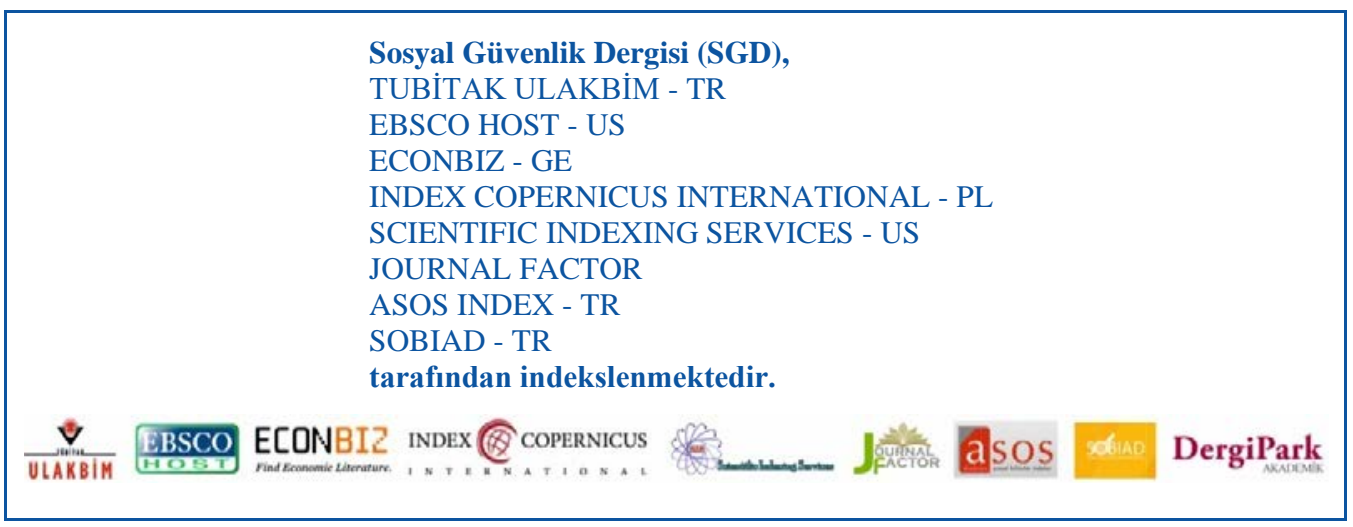

CTüm hakları saklıdır. Sosyal Güvenlik Dergisi’nde yer alan bilimsel çalışmaların bir kısmı ya da tamamı telif hakları saklı kalmak üzere eğitim, araştırma ve bilimsel amaçlarla çoğaltılabilir. Dergide yayımlanan makalelerdeki fikir ve görüşler Sosyal Güvenlik Kurumunun kurumsal görüşünü yansıtmaz, tüm görüşler yazarlarına aittir.

Tasarım / Design: PERSPEKTİF Matbaacılık Tasarım Tic.Ltd.Şti. (0 312) 3842055 - Ankara

Basım Yeri / Printed in: PERSPEKTİF Matbaacılık Tasarım Tic.Ltd.Şti. (0 312) 3842055 - Ankara

İletişim Bilgileri / Contact Information

Sosyal Güvenlik Kurumu Başkanlığı

Ziyabey Caddesi No: 6 Balgat / Ankara / TÜRKIYE

Tel / Phone: +90 3122078891 - 2078770 - Faks / Fax: +90 3122077819

Erişim/Webpage: http://www.sgk.gov.tr/wps/portal/sgk/sgd/tr - e-posta / e-mail: sgd@sgk.gov.tr 
Professor Yener ALTUNBAȘ

Bangor University - UK

Professor Paul Leonard GALLINA

Bishop’s University - CA

Professor Jacqueline S.ISMAEL

University of Calgary - CA
Professor Özay MEHMET

University of Carleton - CA

Professor Allan MOSCOVITCH

University of Carleton - CA

Professor Mark THOMPSON

University of British Columbia - CA
Asst. Prof. Sara HSU

State University of New York- USA

Asst. Prof. C. Rada Von ARNIM

University of Utah - USA

\section{ULUSAL DANIŞMA KURULU / NATIONAL ADVISORY BOARD}

Prof. Dr. Ahmet Cevat ACAR

İstanbul Üniversitesi

İşletme Fakültesi

Prof. Dr. İsmail AĞIRBAŞ

Ankara Üniversitesi

Sağlık Bilimleri Fakültesi

Prof. Dr. Levent AKIN

Ankara Üniversitesi

Hukuk Fakültesi

Prof. Dr. Yusuf ALPER

Bursa Uludağ Üniversitesi

İktisadi ve İdari Bilimler Fakültesi

Prof. Dr. Faruk ANDAÇ

Cağ Üniversitesi

Hukuk Fakültesi

Prof. Dr. Kadir ARICI

Ankara Hacı Bayram Veli Üniversitesi

Hukuk Fakültesi

Prof. Dr. Onur Ender ASLAN

Ankara Sosyal Bilimler Üniversitesi

Siyasal Bilgiler Fakültesi

Prof. Dr. Zakir AVŞAR

Ankara Hacı Bayram Veli Üniversitesi

İletișim Fakültesi

Prof. Dr. Ufuk AYDIN

İstanbul Aydın Üniversitesi

Hukuk Fakültesi

Prof. Dr. Abdurrahman AYHAN

Kıbris İlim Üniversitesi

Hukuk Fakültesi

Prof. Dr. Serpil AYTAÇ

Bursa Uludağ Üniversitesi

İktisadi ve İdari Bilimler Fakültesi

Prof. Dr. Mehmet BARCA

Ankara Sosyal Bilimler Üniversitesi

Siyasal Bilgiler Fakültesi

Prof. Dr. Süleyman BAŞTERZI

Ankara Üniversitesi

Hukuk Fakültesi

Prof. Dr. Nursen CANIKLİOĞLU

Marmara Üniversitesi

Hukuk Fakültesi

Prof. Dr. Fevzi DEMIR

Yaşar Üniversitesi

Hukuk Fakültesi
Prof. Dr. A. Murat DEMIRCİOĞLU

Yıldız Teknik Üniversitesi

Emekli Öğretim Üyesi

Prof. Dr. Ömer EKMEKÇI

İstanbul Üniversitesi

Hukuk Fakültesi

Prof. Dr. E. Murat ENGIN

Galatasaray Üniversitesi

Hukuk Fakültesi

Prof. Dr. Hediye ERGİN

Marmara Üniversitesi

İktisat Fakültesi

Prof. Dr. Şükran ERTÜRK

Dokuz Eylül Üniversitesi

Hukuk Fakültesi

Prof. Dr. Afsun Ezel ESATOĞLU

Ankara Üniversitesi

Sağlık Bilimleri Fakültesi

Prof. Dr. Ali GÜZEL

Kadir Has Üniversitesi

Hukuk Fakültesi

Prof. Dr. Alpay HEKIMLER

Tekirdağ Namık Kemal Üniversitesi

İktisadi ve İdari Bilimler Fakültesi

Prof. Dr. Oğuz KARADENIZ

Pamukkale Üniversitesi

İktisadi ve İdari Bilimler Fakültesi

Prof. Dr. Aşkın KESER

Bursa Uludağ Üniversitesi

İktisadi ve İdari Bilimler Fakültesi

Prof. Dr. Cem KILIC

TOBB Ekonomi ve Teknoloji Üniversitesi

İktisadi ve İdari Bilimler Fakültesi

Prof. Dr. Ali Riza OKUR

İstanbul Sabahattin Zaim Üniversitesi

Hukuk Fakültesi

Prof. Dr. Serdar SAYAN

TOBB Ekonomi ve Teknoloji Üniversitesi

İktisadi ve İdari Bilimler Fakültesi

Prof. Dr. Ali Nazım SÖZER

Yaşar Üniversitesi

Hukuk Fakültesi

Prof. Dr. Sarper SÜZEK

Atılım Üniversitesi

Hukuk Fakültesi
Prof. Dr. Müjdat SAKAR

Marmara Üniversitesi

İktisat Fakültesi

Prof. Dr. Savas TASKENT

İstanbul Teknik Üniversitesi

İşletme Fakültesi

Prof. Dr. Ferda YERDELEN TATOĞLU

İstanbul Üniversitesi

İktisat Fakültesi

Prof. Dr. Sabri TEKİR

İzmir Demokrasi Üniversitesi

İktisadi ve İdari Bilimler Fakültesi

Prof. Dr. Mehmet TOP

Hacettepe Üniversitesi

İktisadi ve İdari Bilimler Fakültesi

Prof. Dr. Türker TOPALHAN

Ankara Hacı Bayram Veli Üniversitesi

İktisadi ve İdari Bilimler Fakültesi

Prof. Dr. Aziz Can TUNCAY

Bahçeşehir Üniversitesi

Hukuk Fakültesi

Prof. Dr. M. Fatih USAN

Ankara Yıldırım Beyazıt Üniversitesi

Hukuk Fakültesi

Prof. Dr. Gülbiye YENIMAHALLELI

Ankara Üniversitesi

Sağlık Bilimleri Fakültesi

Doç. Dr. Gaye BAYCIK

Ankara Üniversitesi

Hukuk Fakültesi

Doc. Dr. Emel İSLAMOĞLU

Sakarya Üniversitesi

Siyasal Bilgiler Fakültesi

Doç. Dr. Saim OCAK

Marmara Üniversitesi

Hukuk Fakültesi

Doç. Dr. Ercüment ÖZKARACA

Marmara Üniversitesi

Hukuk Fakültesi

Doç. Dr. Sinem YILDIRIMALP

Sakarya Üniversitesi

Siyasal Bilgiler Fakültesi 
Prof. Dr. Levent AKIN

Ankara Üniversitesi

Hukuk Fakültesi

Prof. Dr. Yusuf ALPER

Bursa Uludağ Üniversitesi

İktisadi ve İdari Bilimler Fakültesi

Prof. Dr. Murat ATAN

Ankara Hacı Bayram Veli Üniversitesi

İktisadi ve İdari Bilimler Fakültesi

Prof. Dr. Sibel ATAN

Ankara Hacı Bayram Veli Üniversitesi

İktisadi ve İdari Bilimler Fakültesi

Prof. Dr. Şenay ÜÇDOĞRUK BİRECIKLII

Dokuz Eylül Üniversitesi

İktisadi ve İdari Bilimler Fakültesi

Prof. Dr. Nurşen CANIKLİĞGLU

Marmara Üniversitesi

Hukuk Fakültesi

Prof. Dr. Elif GÖKÇEARSLAN ÇİFTÇİ

Ankara Üniversitesi

Sağlık Bilimleri Fakültesi

Prof. Dr. Ömer EKMEKÇİ

İstanbul Üniversitesi

Hukuk Fakültesi

Prof. Dr. Zeki ERDUT

Dokuz Eylül Üniversitesi

İktisadi ve İdari Bilimler Fakültesi

Prof. Dr. Atilla GÖKÇE

Ankara Hacı Bayram Veli Üniversitesi

İktisadi ve İdari Bilimler Fakültesi

Prof. Dr. Banu UÇKAN HEKIMLER

Anadolu Üniversitesi

İktisadi ve İdari Bilimler Fakültesi

Prof. Dr. Cemal İYEM

Aydın Adnan Menderes Üniversitesi

Söke İşletme Fakültesi
Prof. Dr. İlknur KILKIS

Bursa Uludağ Üniversitesi

İktisadi ve İdari Bilimler Fakültesi

Prof. Dr. Handan KUMAŞ

Pamukkale Üniversitesi

İktisadi ve İdari Bilimler Fakültesi

Prof. Dr. Umut OMAY

İstanbul Üniversitesi

İktisat Fakültesi

Prof. Dr. Kamil ORHAN

Pamukkale Üniversitesi

İktisadi ve İdari Bilimler Fakültesi

Prof. Dr. Serap PALAZ

Bandırma Onyedi Eylül Üniversitesi

İktisadi ve İdari Bilimler Fakültesi

Prof. Dr. Faruk SAPANCALI

Dokuz Eylül Üniversitesi

İktisadi ve İdari Bilimler Fakültesi

Prof. Dr. Filiz Elmas SARAC

Ankara Hacı Bayram Veli Üniversitesi

İktisadi ve İdari Bilimler Fakültesi

Prof. Dr. Ferda YERDELEN TATOĞLU İstanbul Üniversitesi

İktisat Fakültesi

Prof. Dr. Aysen TOKOL

Bursa Uludağ Üniversitesi

İktisadi ve İdari Bilimler Fakültesi

Prof. Dr. Suat UĞUR

Çanakkale Onsekiz Mart Üniversitesi

Biga İktisadi ve İdari Bilimler Fakültesi

Prof. Dr. Handan YOLSAL

İstanbul Üniversitesi

İktisat Fakültesi

Doç. Dr. Erdem CAM

Ankara Üniversitesi

Siyasal Bilgiler Fakültesi
Doç. Dr. Hamdi EMEÇ

Dokuz Eylül Üniversitesi

İktisadi ve İdari Bilimler Fakültesi

Doç. Dr. Furkan EMIRMAHMUTOĞLU Ankara Hacı Bayram Veli Üniversitesi İktisadi ve İdari Bilimler Fakültesi

Doç. Dr. Aycan HEPSAĞ

İstanbul Üniversitesi

İktisat Fakültesi

Doç. Dr. Recep KAPAR

Muğla Sitkı Koçman Üniversitesi

İktisadi ve İdari Bilimler Fakültesi

Doç. Dr. Serdar KURT

Çanakkale Onsekiz Mart Üniversitesi

Biga İktisadi ve İdari Bilimler Fakültesi

Doç. Dr. Banu METİN

Ankara Hacı Bayram Veli Üniversitesi

İktisadi ve İdari Bilimler Fakültesi

Doç. Dr. Nagihan DURUSOY ÖZTEPE Pamukkale Üniversitesi

İktisadi ve İdari Bilimler Fakültesi

Doç. Dr. Ramazan ŞAHIN

Gazi Üniversitesi

Mühendislik Fakültesi

Doç. Dr. Özgür TOPKAYA

Çanakkale Onsekiz Mart Üniversitesi Biga İktisadi ve İdari Bilimler Fakültesi

Doç. Dr. Özlem YORULMAZ

İstanbul Üniversitesi

İktisat Fakültesi

Dr. Öğr. Üyesi Ömer DORU

Mardin Artuklu Üniversitesi

İktisadi ve İdari Bilimler Fakültesi

Dr. Öğr. Üyesi Özlem GÖKTAŞ

İstanbul Üniversitesi

İktisat Fakültesi

Dr. Cihan Serhat KART

Ankara Üniversitesi

Ayaş Meslek Yüksekokulu 


\section{SAYI DEĞERLENDİRME ISTATISSTIKLERİ}

EVALUATION STATISTICS FOR THIS ISSUE

Toplam gelen makale başvurusu

Yayına kabul edilen makale sayısı

Hakem süreci devam eden makale sayısı

Red edilen makale sayıs

Ön inceleme aşamasında red edilen makale sayısı

Makale kabul oranı
Number of received manuscript

39

Number of accepted manuscript

Under consideration

Rejected after evaluation

Rejected before evaluation

2

Accepted manuscript rate

$\% 35$ 
Araştırma Makalesi - Research Article

\section{Eğitim-İstihdam ve Eğitim-Gelir Etkinliği:} Yükseköğretime Katılımın OECD Ülkeleri Bazında Panel Veri Analizi

\section{Education-Employment and Education-Income Effectiveness: Panel Data Analysis of the Participation in Higher Education Based on OECD Countries}

\author{
Fatma YEŞILKAYA* \\ (iD) 0000-0002-1766-3535 \\ Türker TOPALHAN** \\ (iD) 0000-0002-3910-2720 \\ Sezin ÜNAL MİÇOOĞULLARI***
(iD) 0000-0002-9656-4606
}

Sosyal Güvenlik Dergisi / Journal of Social Security Cilt: 10 Say1: 2 Y11: 2020 / Volume: 10 Issue: 2 Year: 2020 Sayfa Aralı̆ı̆: 413-430 / Pages: 413-430

DOI: $10.32331 /$ sgd.841019

\section{ÖZ}

Çalışmanın temel amacı, yükseköğretime katılımın istihdama katılım noktasında beklendiği ölçüde artırıcı etkiye sahip olamaması ve çalışanların milli gelirden aldıkları payda yaşanan düşüşten hareketle yükseköğretime katılımın, istihdam üzerindeki ve çalışanların gayrisafi yurtiçi hasıladan aldıkları pay üzerindeki etkisinin panel veri analizi uygulanarak tespit edilmesidir. $\mathrm{Bu}$ çalışma kapsamında, yükseköğretime katılım açıklayıcı değişken, istihdam oranı ve çalışanların gayrisafi yurtiçi hasıladan aldıkları pay ise bağımlı değişken olarak belirlenmiş, 2005-2016 yılları arasında OECD kurucu üyesi olan 20 ülke analiz kapsamında incelenmiştir. Çalışmada iki model kurulmuş, ilk modelde yükseköğretime katılımın istihdam ile iliş̧isi ikinci modelde ise çalışanların gayrisafi yurtiçi hasıladan aldıkları pay ile ilişkisi incelenmiştir. Analiz sonucu elde edilen bulgular literatürü destekler nitelikte olup, yükseköğretime katılım ile istihdam arasında pozitif yönlü bir ilişki, yükseköğretime katılım ile çalışanların gayrisafi yurtiçi hasıladan aldıkları pay arasında negatif yönlü bir ilişki tespit edilmiştir.

Anahtar Sözcükler: Beşeri sermaye, panel veri analizi, yükseköğretime katılım

\begin{abstract}
The main purpose of the study is that the participation to higher education is not expected to have an increasing effect on the point of participation in employmet and moving from decline of the share of the national income, we aim to determine the contribution of the participation in higher education on employment and the share of the employees on gross domestic product by applying panel data analysis. In this study, participation in higher education was defined as an explanatory variable, employment rate and the share of employees from the gross domestic product as dependent variable, Between 2005 and 2016, 20 countries that are the founding members of OECD are examined within the scope of the analysis. In the study, two models were established and in the first model, the relationship between employment and participation in higher education and in the second model, the relationship between the share of employees from the gross domestic product is examined. The findings of the analysis support the literature, a positive relationship has been found between participation in higher education and employment, and a negative relationship between participation in higher education and the share of employees from the gross domestic product.
\end{abstract}

Keywords: Human capital, panel data analysis, participation in higher education
Önerilen atıf şekli: Yeşilkaya, F., Topalhan, T. ve Ünal Miçooğulları, S. (2020). Eğitim-İstihdam ve Eğitim-Gelir
Etkinliği: Yükseköğretime Katılımın OECD Ülkeleri Bazında Panel Veri Analizi. Sosyal Güvenlik Dergisi (Journal of
Social Security). 10(2). 413-430

Geliş Tarihi/Received: 17/04/2020 • Güncelleme Tarihi/Revised: 17/11/2020 • Kabul Tarihi/Accepted: 16/12/2020

\footnotetext{
* $\quad$ Arş. Gör., Mersin Üniversitesi, İktisadi ve İdari Bilimler Fakültesi, Çalışma Ekonomisi Endüstri İlişkileri Bölümü, fatmayesilkaya58@gmail.com

** Prof. Dr., Ankara Hacı Bayram Veli Üniversitesi, İktisadi ve İdari Bilimler Fakültesi, Çalışma Ekonomisi Endüstri İlişkileri Bölümü, turker.topalhan@hbv.edu.tr

*** Arş. Gör., Ankara Hacı Bayram Veli Üniversitesi, İktisadi ve İdari Bilimler Fakültesi, Çalışma Ekonomisi Endüstri İlişkileri Bölümü, sezin.micoogullari@hbv.edu.tr
} 


\section{GíRíş}

Günümüzde eğitimin özellikle yükseköğretimin önemi, kalkınmanın gerçekleşmesi ve nitelikli işgücü yetiştirilmesi konusunda kendini göstermektedir. Nitelikli işgücünün eğitimle gerekli bilgi ve beceriyi kazanması, istihdamın artırılmasını ve iktisadi büyümeyi sağlarken aynı zamanda da küreselleşen dünyada rekabet edebilmenin anahtarı konumundadır. Yükseköğretime katılan kişilerin işgücü piyasasına daha kolay girmesi ve istihdamın artırılması konusunda eğitimin önemi hem iktisadi hem de sosyal bir sorun alanıdır. İktisat politikaları belli bir noktada sorunların üstesinden gelme konusunda yetersiz kalmaya başlayınca, özellikle 20.yy'ın yarısından itibaren ülkelerin kalkınma aşamasında karşılaştıkları problemlerin çözümü olarak beşeri sermaye kuramı dikkate alınmaya başlamıştır. Bu kuram doğrultusunda beşeri sermayede yaşanan birikim aynı zamanda fiziksel sermayede de etkinlik artışına ve teknolojik ilerlemeye de fayda sağlamaktadır. Fiziksel ve beşeri sermayede gerçekleşen birikim sonucunda verimlik artmakta uzun dönemde ekonomik büyümeye pozitif katkı sağlamaktadır. Eğitim hem bireylere hem de topluma bir maliyet yüklerken, bireylerin ve toplumun ne derece fayda elde ettiğini tespit etmek zor olsa da eğitime yapılan yatırımın bireyin kendisine de toplumun refahına da katkı sağladığı bir gerçektir (Karataş ve Çankaya, 2010; Özyakışır, 2011). Beşeri sermaye kuramıyla da yakından ilgili olan eğitimin önemi, beşeri sermaye birikiminin artırılması bireysel manada olduğu kadar toplumsal refah açısından da önemlidir. Çünkü işi olmayan bireyler ülke için refah kaybı yaratmakta ve tam istihdam sağlanamamaktadır. Eğitim istihdam ilişkisinin doğru kurulması hem istihdamı artıracak hem de ekonomik büyümeyi sağlayacaktır (Gölpek, 2011).

Ancak eğitimli bireylerin gayrisafi yurtiçi hasıladan aldığı payın düşmesi bu söylenenlerle pek uyuşmamaktadır. Çalışmanın da konusu olan bu sorun aslında 70'lere dayanmaktadır. Emeğin ulusal gelirden aldığı pay hızla düşmeye başlamış ve 80 'lerle beraber bazı işler tamamen ortadan kalkmış bazılarının değeri azalmış ve bilgi teknolojisi geliştikçe emeğin gelirden aldığı pay azalmıştır. 2000'lere gelindiğinde maaşlardaki artışlar üretimdeki artışların yanında çok küçük kalmıştır. Ulusal gelirden emeğe giden pay hızla azalmıştır. 2013 Haziran'ında Chicago Üniversitesi'nde yapılan bir araştırmada, Karabarbounis ve Neiman (2013), 56 ülkenin verilerini incelenmiş ve 38 ülkede ulusal gelirden emeğin aldığı payların azaldığı bulgusuna ulaşılmışlardır. $\mathrm{Bu}$ durumun nedenini ise sermaye üreten sektörlerdeki, bilgi teknolojisi ve bilgisayar çağına atfedilen verim artışı olarak açıklamışlardır. Günümüzde sadece üniversite mezunu olmanın çok önemli olmadığı yapılan araştırmalarla da desteklenmektedir. Buna göre; 2000-2010 yılları arasında lisans mezunlarının gelirleri \%15 azalmıştır. Buna benzer şekilde yeni üniversite mezunları arasında işsizlik oranlarının artmasının yanı sıra birçoğu da eğitimini aldıkları işlerde çalışmamaktadır. Araştırmalar göstermektedir ki, hem finans sektöründeki büyüme ile eşitsizlik arasında hem de ulusal gelirde emeğe düşen payın azalması arasında güçlü bir paralellik bulunmaktadır (Ford, 2018: 60-83).

$\mathrm{Bu}$ çalışmada beşeri sermayenin temel belirleyicilerinden olan eğitimin önemli bir unsuru olan yükseköğretimin istihdama ve çalışanların gayrisafi yurtiçi hasıladan aldıkları paya etkisini incelemek üzere 2 model kurulmuş ve panel veri analizi yapılmıştır. İlk modelde yükseköğretime katılımın istihdam üzerindeki etkisi, ikinci modelde ise çalışanların gayrisafi yurtiçi hasıladan aldıkları pay üzerindeki etkisi araştırılmıştır. Analize konu olan ülkeler OECD kurucu üyesi olan 20 ülke olarak belirlenmiş ve zaman aralığ 2005-2016 olarak belirlenmiştir. 12 yıla ait bağımlı değişkenler istihdam ve çalışanların gayrisafi yurtiçi hasıladan aldıkları pay ve açıklayıcı değişken olan yükseköğretime katılım verileri panel veri analizi yapılarak incelenmiştir. Değişkenlerle ilgili verilere OECD ve ILO veri tabanları 
üzerinden erişilmiştir. Değişkenlerin belirlenmesinde seçilen ülkelere ait tüm verilerin eksiksiz ve aynı yıla ilişkin veriler olması dikkate alınmıştır. Çalışma kapsamında ilk olarak literatürde beşeri sermaye konusunda yapılan çalışmalar incelenmiş, sonrasında analiz kısmına geçilmiştir.

\section{I- ULUSAL VE ULUSLARARASI LITERATÜR}

Çalışmanın bu bölümünde beşeri sermaye üzerine ulusal ve uluslararası literatürde yapılmış olan çalışmalara kronolojik sıra gözetilerek yer verilmiştir. Eğitimin istihdama, ekonomik büyümeye ve gelire olan etkisine yönelik yapılan çalışmalar ve bu çalışmalar sonucunda ulaşılan bulgular ulusal literatür ve uluslararası literatür olacak şekilde anlatılmıştır.

Karagül (2003), yaptı̆̆ çalışmada beşeri sermaye ve ekonomik büyüme arasındaki ilişkiyi incelemişlerdir. Özellikle son yıllarda önemi artan beşeri sermayenin yanı sıra çalışmada iktisadi büyüme ve gelişme politikaları ele alınmıştır. Çalışmada, beşeri sermayede artış yaşanabilmesinin yolunun eğitimli ve sağlıklı bir toplumdan geçtiği vurgulanmakta ve yalnızca beșeri sermayenin etkin kullanılmasının yeterli olmadığı beşeri sermaye ve fiziksel sermayenin birbirlerini tamamlayıcı bir ilişki içerisinde olmaları gerektiği belirtilmiştir.

Çoban (2004), Türkiye’de 1980-1997 yılları arasında eğitimle ilişkili çeşitli değişkenler ile GSMH değişkeni arasındaki ilişkiyi analiz etmiştir. Çalışmada Johansen eş bütünleşme testi kullanılarak GSMH değişkeni ve eğitime ilişkin değişkenler arasındaki uzun dönem ilişki incelenmiştir. Eğitimle ilişkili seçilen değiş̧enlerle GSMH arasında uzun dönem ilişkisi saptanmış ve sonrasında Granger nedensellik testi uygulanmıştır. Buna göre, ilkokul okullaşma oranının artmasının ekonomik büyümeyi, ekonomik büyümedeki artışın ise lise okullaşmasında artışa neden olduğu sonucuna ulaşılmıştır.

Serel ve Masatçı (2005), 1950-2000 döneminde Türkiye'de beşeri sermaye ve ekonomik büyüme arasındaki ilişkiyi inceledikleri çalışmalarında orta öğretimde kayıtlı olan öğrenci sayısı, toplam işgücü, sabit sermaye yatırımları ve GSMH değişkenler olarak belirlenmiştir. Çalışmada yapılan analizle beşeri sermayenin ekonomik büyüme üzerindeki pozitif yöndeki etkisi tespit edilmiştir.

Özsoy (2009)'un, 1923-2005 yıllarını esas alarak yaptığı çalışmasında Türkiye'de eğitim ile ekonomik büyüme arasındaki ilişki incelenmiştir. VAR modelinin kullanıldığı çalışmada, eğitim göstergesi olarak öğrenci sayıları; ekonomik büyüme göstergesi olarak ise reel GSYİH seçilmiştir. Çalışmada Türkiye'de ekonomik büyüme ile eğitim arasında pozitif yönlü ilişki olduğu tespit edilmiştir.

Karataş ve Çankaya (2011), Türkiye'de 1981-2006 yıllarında beşeri sermaye yatırımlarının ekonomik büyüme üzerindeki etkisinin analiz edildiği çalışmalarında kişi başına reel GSYİH'yi bağımlı değişken olarak belirlemişlerdir. Açıklayıcı değişkenler olarak ise beşeri sermaye göstergesi olarak eğitim harcamalarının GSYİH içindeki payı, yükseköğretim okullaşma oranı, sağlık harcamalarının GSYİH içindeki payı ile son olarak fiziki sermaye göstergesi olarak sabit sermaye yatırımlarının GSYİH içerisindeki payı olarak belirlenmiştir. Elde edilen bulgulara göre; Türkiye'de ekonomik büyüme aşamasında fiziki sermayeye yapılan yatırımların daha etkin olduğu sonucuna ulaşılmaktadır.

Akgül ve Koç (2011), Türkiye’de 1914-2009 yılları arasında yükseköğretim ve ekonomik büyüme arasındaki ilişkinin varlığını araştırmışlardır. GSMH ve yükseköğretim mezunu kişi sayısı çalışmada TAR modeli uygulanarak araştırılmıştır. Çalışma sonucunda, eğitim ekonomik büyümenin önemli bir bileşeni olarak gösterilmektedir. 
Gölpek (2011) tarafından yapılan çalışmada yükseköğretimin getirileri ve etkinlik sorunu üzerinde durulmuştur. İlk kısımda eğitimin getirileri üzerinde durulan çalışmanın ikinci kısmında yükseköğretimde etkinlik sorunu ele alınmaktadır. Bu çalışmaya göre; özel getiriler kapsamında en etkin olan eğitim kademesi yükseköğretim iken, sosyal getiriler kapsamında en az etkin olan eğitim kademesi yükseköğretimdir. Yükseköğretimin hem maliyetlerinin yüksek oluşu hem yüksek gelir grubuna dahil ailelerin çocuklarının yükseköğretime katıllyor oluşu hem de ögrencilerin mezun olma sürelerinin uzun oluşu yükseköğretimi diğer eğitim kademelerine göre daha az etkin hale getirmektedir. Bu noktadan hareketle varılan sonuç, ülkemiz için ilk ve ortaöğretime yapılan kamu kaynaklı yatırımların yükseköğretime yapılan yatırımlara nazaran artırılması gerektiğidir.

Ekinci (2011)'nin yaptığı çalışmada ise, sosyo-ekonomik etmenlerin yükseköğretime katılım üzerindeki etkileri incelenmiştir. Araştırmadan, yükseköğretime giriş aşamasında gelirin doğrudan belirleyici bir etkiye sahip olmadığ 1 sonucuna ulaşılmıştır.

Keskin (2011) yaptığı çalışmada, beşeri sermaye ile ekonomik kalkınma ilişkisini hem Türkiye için hem de diğer ülkeler için incelemiş ve karşılaştırmalı bir analiz gerçekleştirmiştir. Çalışmada, 177 ülke için çoklu doğrusal regresyon modeli oluşturulmuş ve beşeri sermaye ve ekonomik kalkınma arasındaki ilişki incelenmiştir. Elde edilen analiz sonucunda, ekonomik kalkınma olgusunda okuryazarlık oranı ve eğitim düzeyinin, kamu eliyle yürütülen sağlık harcamalarının ve R\&D harcamalarının belirleyici olduğu tespit edilmiştir.

Erdem ve Tuğcu (2012), Türkiye'de yükseköğretim ve işsizlik arasındaki ilişkiyi 1960-2007 dönemine ait verilerle nedensellik ve eşbütünleşme analizleri kullanarak inceledikleri çalışmalarında; Türkiye'de kısa ve uzun vadede işsizlik oranlarını artıran faktörlerden birinin yükseköğretim mezunları olduğu sonucuna ulaşılmıştır.

Eriçok ve Yılancı (2013), 1968-2005 yılları için ekonomik büyüme ve eğitim harcamaları arasındaki ilişkiyi inceledikleri çalışmalarında sınır testi yaklaşımıyla, GSYİH ve eğitim harcamaları analiz edilmiştir. Çalışmada, eğitim harcamalarının ekonomik büyümeyi etkilediği fakat bu etkinin geçici olduğu sonucuna ulaşılmıştır.

Akça (2014) ise, 1960-2010 yılları için Türkiye'de beşeri sermayenin ekonomik büyümeye etkisini analiz etmiştir. Çalışmada, ekonomik büyümeyi temsilen gayrisafi yurtiçi hasıla oranı, beşeri sermayeyi temsilen eğitim göstergeleri kullanılmıştır. Eğitim göstergeleri olarak, yükseköğretim okullaşma oranı ile ilköğretim ve yükseköğretim kademelerinde okul başına düşen öğrenci sayıları kullanılmıştır. Çalışmada zaman serisi analizleri kullanılmış ve analizden elde edilen bulgular, beşeri sermaye ile ekonomik büyüme göstergeleri arasında uzun dönemli ilişkinin varlığını ortaya koymuştur. Analiz sonuçlarına göre, Türkiye'de uzun dönemde, beşeri sermayenin ekonomik büyüme üzerine pozitif bir etkisinin olduğu görülmüştür.

Uysal ve Aydemir (2016)'in yaptıkları çalışmada eğitim ve beşeri sermaye kapsamında yükseköğretim üzerinde durulmuş, bireylerin eğitim seviyesinde yaşanan artışla istihdam arasındaki ilişkiye yönelik ekonometrik bir analiz gerçekleştirilmiştir. Türkiye kapsamında 1994-2014 yılları için yapılan analize göre; eğitim seviyesinde yaşanan artışın istihdama katılım noktasında karşılık bulamadığı yani Türkiye'de eğitim seviyesinde yaşanan yükselişin istihdam artışına sebep olamadığı sonucuna ulaşılmıştır.

Abdioğlu ve Albayrak (2018)'in yaptıkları çalışma kapsamında beşeri sermayenin ekonomik büyümeye etkisi 1988-2015 dönemleri için Türkiye'de tarım, sanayi ve hizmetler sektörlerinde ARDL sınır testi ve hata düzeltme modeli ile incelenmektedir. Çalışmada beşeri 
sermaye göstergesi olarak yükseköğretim mezunu öğrenci sayısı kullanılmıştır. Yapılan analiz sonucunda elde edilen bulgulara göre; yükseköğretimdeki öğrenci sayısı ile ekonomik büyüme arasında uzun dönemli bir ilişki bulunmakta, sektörel kapsamda ise yükseköğretimdeki öğrenci sayısında yaşanan artış en fazla hizmetler sektörünü etkilemektedir.

Brauns vd. (1999), farklı eğitim sistemleri ve işgücü piyasası karakterlerine sahip olan Almanya, Fransa ve Birleşik Krallık için eğitimin işgücü piyasasından dışlanmayı engellediği tezinden hareketle 1980'lerin ortasından 1990'ların ortasına kadar olan sürece ilişkin mikro verilerden hareketle yaptıkları karşılaştırmalı analizde tek aşamalı ve sıralı lojistik regresyon modelleri kullanılmıştır. Analiz bulgularına göre; her üç ülkede de eğitimin işsizlik riskini azalttığı fakat üç ülke için eğitimsel tabakalaşma konusunda keskin bir ayrım olduğu ortaya koyulmaktadır.

Blankenau vd. (2007), 23 gelişmiş ülke için panel veri analizi metoduyla yaptıkları çalışmada, kamu eliyle yürütülen eğitim harcamaları ile uzun dönemli büyüme arasındaki pozitif ilişkinin, bütçe kontrol edildiği takdirde gerçekleşeceği tespit edilmiştir. Yoksul ülkelerde ise, bütçe kontrol edilse dahi, kamu eliyle yürütülen eğitim harcamalarının uzun dönemli büyüme üzerinde bir etkisi olmadığı sonucuna ulaşılmıştır.

Nunez ve Livanos (2010), 15 Avrupa ülkesinde akademik kariyer derecesinin uzun ve kısa dönemli işsizlik üzerine etkilerini çok terimli lojistik regresyon yöntemi (M-Logit) kullanarak inceledikleri çalışmalarında, kısa ve uzun dönemde yükseköğretime katılımın istihdam şansını artırdığı ve özellikle uzun dönemde işsizliği azaltıcı yönde etkide bulunduğu tespit edilmiştir.

Riasat vd. (2011), ekonomik büyümenin eğitim üzerindeki etkisini Pakistan için araştırdıkları çalışmalarında ARDL yöntemini kullanmışlardır. Yapılan analiz sonucunda, eğitim harcamalarının ekonomik büyümede uzun dönemde önemli düzeyde etkili olduğu fakat kısa dönemde olmadığı sonucuna ulaşılmıştır.

Riddell ve Song (2011)'un çalışmalarında, ABD'de eğitimin istihdam ve işsizlik geçişlerindeki nedensel etkileri 1980-2005 yılları verilerinden hareketle enstrümantal değişkenler ve en küçük kareler yöntemleriyle araştırılmıştır. Sonuçlar incelendiğinde; eğitimin, işsizlerin yeniden istihdama katılım oranlarını önemli ölçüde artırdığı, özellikle bu artışın yüksek eğitim düzeylerinde daha fazla gerçekleştiği görülmektedir.

Lavrinovicha vd. (2015)'nın çalışmalarında Letonya'da 2002-2013 yılları arasında eğitimin işsizlik oranı ve gelir üzerindeki etkisini frekans, korelasyon ve regresyon yöntemleri aracılığıyla araştırılmaktadır. Yapılan analizlerle eğitimin istihdamı ve gelir düzeyini artırıcı etkisi olduğu ortaya koyulmuş̧tur.

Hunady ve Pisar (2016) tarafından yapılan çalışmada 316 NUTS II bölgesine ilişkin 20042014 yılları verileriyle yükseköğretim almış kişilerin payı ile GSYİH'yi etkileyen bölgesel işsizlik düzeyi arasındaki ilişkiyi panel veri analizi yöntemiyle incelenmiştir. Analiz sonucunda, yükseköğretim almış kişilerin payında yaşanan artışın bölgesel işsizlik üzerinde negatif yani azaltıcı bir etkisi olduğu tespit edilmiştir.

\section{II- ANALIZ}

Çalışmanın uygulama bölümünde istihdam oranı ile bu orana etki ettiği düşünülen yükseköğretime katılım oranına ilişkin ve çalışanların gayrisafi yurtiçi hasıladan aldıkları pay ile yükseköğretime katılım oranına ilişkin gerçekleştirilen analizler yer almaktadır. 


\section{A-Veri Seti ve Tanımlayıcı İstatistikler}

Çalışmada yükseköğretime katılmış olmanın istihdam ve çalışanların gayrisafi yurtiçi hasıladan aldıkları pay üzerindeki etkisi belirlenmeye çalışılmıştır. 2005-2016 yılları arasında OECD kurucu üyesi olan 20 ülke analiz kapsamında incelenmiştir. Araştırma kapsamında incelenen ülkeler Tablo 1'de gösterilmektedir.

Tablo 1. Araştırma Kapsamında İncelenen Ülkeler
1. ABD
2. Almanya
11. İsveç
3. Avusturya
12. İsviçre
4. Belçika
5. Danimarka
13. İtalya
14. İzlanda
15. Kanada
6. Fransa
16. Lüksemburg
7. Hollanda
17. Norveç
8. İngiltere
18. Portekiz
9. İrlanda
19. Türkiye
10. İspanya
20. Yunanistan

Çalışmada istihdam oranı ve çalışanların gayrisafi yurtiçi hasıladan aldıkları pay bağımlı değişken, yükseköğretime katılım oranı ise açıklayıcı değişken olarak belirlenmiştir. Bu iliş̧inin belirlenmesinde, ŞİMŞEK ve KADILAR (2010), GÖLPEK (2011), AKINCI (2017) ve ABDİOĞLU ve ALBAYRAK (2018) tarafından yapılan çalışmalardan faydalanılmıştır. Çalışmada kullanılan veriler OECD veri tabanı ve ILO veri tabanından elde edilmiştir. Tablo 2'de çalışma kapsamında kullanılan değişkenler ve hesaplama şekilleri yer almaktadır.

Tablo 2. Değişkenler ve Hesaplama Şekilleri

\begin{tabular}{lll}
\hline Bağımlı Değişken & İstihdam Oranı & Çalışan nüfusun yüzdesi \\
\hline Bağımlı Değişken & $\begin{array}{l}\text { Çalışanların Gayrisafi Yurtiçi } \\
\text { Hasıladan Aldıkları Pay }\end{array}$ & GSYİH/istihdamdaki kişi sayısı \\
\hline Açıklayıcı Değişken & Yükseköğretime Katılım Oranı & $\begin{array}{l}\text { 25-64 yaşındaki nüfusun } \\
\text { yükseköğretime katılım yüzdesi }\end{array}$ \\
\hline
\end{tabular}

Çalışmada kullanılan değişkenler ve hesaplama şekilleri açıklandıktan sonra değişkenlere ilişkin tanımlayıcı istatistiki değerler hesaplanmıştır. Bu değerler Tablo 3 ’te gösterilmektedir.

Tablo 3. Tanımlayıcı İstatistikler

\begin{tabular}{llll}
\hline & İST & GDP & YO \\
\hline Ortalama & 67.742 & 94195.56 & 31.734 \\
\hline Medyan & 69.365 & 89019.25 & 32.540 \\
\hline Maksimum & 86.530 & 229424.4 & 56.270 \\
\hline Minimum & 44.230 & 54583.40 & 10.240 \\
\hline Std. Sap. & 8.609 & 31143.98 & 9.318 \\
\hline Çarpıklık & -0.571 & 2.471 & -0.216 \\
\hline Basıklık & 3.059 & 10.112 & 3.031 \\
\hline Jarque-Bera & 13.082 & 750.281 & 1.880 \\
\hline Olasılık & 0.001 & 0.000 & 0.390 \\
\hline Gözlem & 240 & 240 & 240
\end{tabular}

Tabloda istihdam oranı (İST) ile çalışanların gayrisafi yurtiçi hasıladan aldıkları pay (GDP) ile yükseköğretime katılım (YO) ile gösterilmektedir. 
Tanımlayıcı istatistik sonuçları değerlendirildiğinde, OECD kurucu üyelerinin istihdam oranlarının göstergesi olan istihdam oranının Jarque-Bera olasılık değerinin 0.001 olduğu, çalışanların gayrisafi yurtiçi hasıladan aldıkları payın Jarque-Bera değerinin 0.000 olduğu, yükseköğretime katılım oranının değerinin ise 0.390 olduğu görülmektedir. Bu durumdan hareketle istihdam ve çalışanların gayrisafi yurtiçi hasıladan aldıkları pay değişkenlerinin normal dağılıma uymadığı, yükseköğretime katılma değişkeninin ise normal dağılıma uyduğu söylenebilmektedir.

\section{B- Yöntem}

Çalışma kapsamında ilk etapta panelin üzerine kurulduğu yatay kesitler (OECD ülkeleri) arasındaki bağımlılık panel ve değişken bazında incelenmiştir. Değişkenlerin katsayılarının yatay kesitler arasındaki değişkenliği ise Homojenlik Testi ile araştırılmıştır. Yatay kesit bağımlılığı ve homojenliği test edildikten sonra serilere ilişkin durağanlık sınaması yapılmıştır. Durağanlık sınaması gerçekleştirildikten sonra modelin hangi yöntem kullanılarak tahmin edileceğini belirlemek için testler uygulanmıştır. Tahmin yöntemi belirlendikten sonra modelde hata terim varyansının tüm gözlemler için aynı olmamasını ifade eden değişen varyans ve otokorelasyon incelenmiştir. Son olarak da modelin tahminlemesi yapılmıştır.

\section{i) Yatay Kesit Bağımııı̆ı̆ının Tespiti}

Yatay kesit bağımlılığının varlığının tespiti analiz bulgularının güvenilirliğini ve doğruluğunu etkileyen bir durumdur (Breusch- Pagan, 1980; Pesaran, 2004). Çalışmada yatay kesit bağımlılığı, Breusch-Pagan (1980) LM testi, Pesaran (2004) CD ve CDlm testleri ile araştırılmıştır. Bu testlerden zaman boyutunun( $\mathrm{T}$ ) yatay kesit boyutundan(N) oldukça büyük olduğu durumlarda (T>N) kullanılanı Breusch-Pagan (1980) LM testi, zaman boyutu ile yatay kesit boyutu arasında fazla bir farkın olmadığı fakat $(\mathrm{T}>\mathrm{N})$ olduğu durumda kullanılanı Pesaran (2004) CDlm testidir. Pesaran (2004) CD testi ise, diğer testlerin aksine yatay kesit boyutunun zaman boyutundan daha büyük olduğu durumlarda $(\mathrm{N}>\mathrm{T})$ kullanılmaktadır.

Tablo 4. Yatay Kesit Bă̆ımlılı̆̆ı Test Sonuçları

\begin{tabular}{|c|c|c|c|c|c|c|c|c|}
\hline \multirow[t]{2}{*}{ Değişken } & \multicolumn{2}{|c|}{$\begin{array}{l}\text { LM } \\
\text { (Breusch; } \\
\text { Pagan,1980) }\end{array}$} & \multicolumn{2}{|c|}{$\begin{array}{l}\text { CDlm } \\
\text { (Pesaran, 2004) }\end{array}$} & \multicolumn{2}{|c|}{$\begin{array}{l}\text { CD } \\
\text { (Pesaran, 2004) }\end{array}$} & \multicolumn{2}{|c|}{$\begin{array}{l}\text { LMadj } \\
\text { (PUY, 2008) }\end{array}$} \\
\hline & İstat. & Olasılık & İstat. & Olasilik & İstat. & Olasılık & İstat. & Olasilık \\
\hline Panel & 626.796 & 0.000 & 22.407 & 0.000 & 15.495 & 0.000 & 88.230 & 0.000 \\
\hline İST & 377.625 & 0.000 & 9.625 & 0.000 & 3.234 & 0.001 & 19.125 & 0.000 \\
\hline YO & 412.816 & 0.000 & 11.430 & 0.000 & -0.635 & 0.263 & 20.837 & 0.000 \\
\hline
\end{tabular}

Tablo 4'te yer alan yatay kesit bağımlılı̆̆ı testleri sonuçları incelendiğinde; tüm testlerde olasılık değerinin kritik değer olan 0.05 'ten küçük olduğu görülmektedir. Çalışmada N (kesit) boyutu T (zaman) boyutundan büyük olduğu için Pesaran CD (2004) sonuçları dikkate alınmıştır. Bu test sonucunda, sıfır hipotezi reddedilmektedir. Yani panelde yatay kesit bağımlılığı problemi söz konusudur. Diğer bir ifade ile OECD ülkelerinden birine gelen bir birim şok diğer ülkeleri de etkilemektedir. Çalışmada (N>T) olduğu için Pesaran CD (2004) test sonuçları değişken bazında yatay kesit bağımlılığı açısından dikkate alınmıştır. Analiz sonucunda, bağımlı değişken olan IST değişkeninin olasılık değeri 0.05 'ten küçük olduğu için $\mathrm{H}_{0}$ hipotezi reddedilmiştir. Açıklayıcı değişken olan YO değişkeninin olasılık değeri 0.05 'ten büyük olduğu için $\mathrm{H}_{0}$ reddedilememiştir, yatay kesit bağımlılığı yoktur. İST 
değişkeninde yatay kesit bağımlılığı söz konusu olduğu için bu değişken için durağanlık sınamasında yatay kesit bağımlılığını göz önünde bulunduran ikinci nesil birim kök testleri kullanılmıştır.

Panel veri analizinde seriler arasında yatay kesit bağımlılı̆̆ söz konusu olmadığında durağanlık sınaması için uygulanması gereken birim kök testleri belirlenirken ilk etapta homojenlik testlerinin yapılması gerekmektedir. Homojenlik testi hem panel için hem de değişkenler için ayrı ayrı yapılabilmektedir.

\section{ii) Parametrelerde Homojenliğin/Heterojenliğin Test Edilmesi}

Yatay kesit bağımlılığı analizi sonrasında, analize geçilmeden önce sınanması gereken diğer bir varsayım homojenliktir. Pesaran ve Yamagata (2008) delta testleri ile homojenlik varsayımı sınanabilmektedir.

Tablo 5. Pesaran ve Yamagata (2008) Homojenite Test Sonuçları

\begin{tabular}{lcccc}
\hline & Delta_tilde & $\begin{array}{c}\text { Olasılık } \\
\text { Değeri }\end{array}$ & Düzeltilmiş_Delta_Tilde & $\begin{array}{c}\text { Olasılık } \\
\text { Değeri }\end{array}$ \\
\hline Panel $(\boldsymbol{\alpha})$ & 2.714 & 0.003 & 3.314 & 0.001 \\
\hline IST & 1.532 & 0.063 & 1.769 & 0.038 \\
\hline YO & 3.786 & 0.000 & 4.372 & 0.000 \\
\hline $\mathrm{H}_{0}:$ Homojenlik vardır. & & & \\
$\mathrm{H}_{1}:$ Homojenlik yoktur. & & & \\
\hline \hline
\end{tabular}

Pesaran ve Yamagata (2008) Homojenite test sonuçları panel bazında değerlendirildiğinde; modele ait delta ve düzeltilmiş delta olasılık değerleri 0.05 'ten küçük olduğu için panel bazında homojenlik olduğunu savunan $\mathrm{H}_{0}$ hipotezi reddedilmektedir. Yani panel bazında heterojenlik söz konusudur. İST ve YO değişkenleri bazında Homojenite Test sonuçları incelendiğinde; İST değişkeninin delta olasılık değeri 0.1 anlamlılık düzeyinden küçük iken düzeltilmiş delta değeri 0.05 'ten küçük olduğu için İST değişkeni için $\mathrm{H}_{0}$ reddedilmiş olup homojenlik yoktur denilebilmektedir. YO değişkeni için, delta olasılık değeri ve düzeltilmiş delta olasılık değeri 0.05 anlamlılık düzeyinden küçük olduğundan dolayı bu değişken için de $\mathrm{H}_{0}$ hipotezi reddedilmiştir. Dolayısıyla YO değişkeni için de heterojenlik söz konusudur.

\section{iii) Panel Birim Kök Testleri}

Panel veri analizinde bağımlı ve açıklayıcı değişkenler arasında anlamlı sonuçlara ulaşılabilmesi için serilerin durağan olması gerekmektedir (Gujarati, 2003). Çalışmada kullanılan değişkenlerin durağanlıkları, yatay kesit bağımlılı̆̆ı ve homojenite durumları göz önünde bulundurularak sınanmıştır. Yatay kesit bağımlılığı testi sonucunda OECD ülkeleri arasında yatay kesit bağımlılı̆̆ının tespit edildiği İST değişkeninin durağanlık sınaması Smith vd. (2004) Bootstrap testi kullanılmıştır. Bu test yatay kesit bağımlılığını göz önünde bulunduran ikincil nesil birim kök testlerindendir. Smith vd. (2004) Bootstrap test sonuçları Tablo 6'da gösterilmektedir.

Tablo 6. Smith vd. (2004) Bootstrap Birim Kök Testi Sonuçları

\begin{tabular}{|c|c|c|c|c|}
\hline \multirow{2}{*}{ Seviye } & \multicolumn{2}{|c|}{ Sabit } & \multicolumn{2}{|c|}{ Sabit ve Trend } \\
\hline & İstatistik & Olas-değeri & İstatistik & Olas-değeri \\
\hline İST & -2.039 & 0.079 & -2.355 & 0.273 \\
\hline \multirow{2}{*}{ Birinci Fark } & \multicolumn{2}{|c|}{ Sabit } & \multicolumn{2}{|c|}{ Sabit ve Trend } \\
\hline & İstatistik & Olas -değeri & İstatistik & Olas -değeri \\
\hline íST & -3.658 & 0.001 & -3.210 & 0.072 \\
\hline $\begin{array}{l}\mathrm{H}_{0} \text { : Birim kök vardır. } \\
\mathrm{H}_{1} \text { : Birim kök yoktur. }\end{array}$ & & & & \\
\hline
\end{tabular}


Tablo 6'daki sonuçlar incelendiğinde; İST değişkenine ait serilerin seviyesinde sabit ve sabit ve trendde durağan olmadıkları, birinci dereceden farkı alındığında sabitte $\% 5$ anlamlılık düzeyinde durağan, sabit ve trendde $\% 10$ anlamlılık düzeyinde durağanlaştığ 1 görülmektedir. Çalışmada incelenen yıl sayısının az olması sebebiyle trendli model yerine sabit model sonuçları dikkate alınmıştır.

Yatay kesit bağımlılı̆̆ olmayan ve heterojen yapıda olan YO değişkeninin durağanlık sınaması için birinci nesil birim kök testleri içerisinde heterojen yapıya sahip olan Im, Pesaran ve Shin (2003) IPS testi kullanılmıştır. IPS test sonuçları Tablo 7'de gösterilmektedir.

Tablo 7. IPS Panel Birim Kök Test Sonuçları

\begin{tabular}{|c|c|c|c|c|}
\hline \multirow{2}{*}{ Seviye } & \multicolumn{2}{|c|}{ Sabit } & \multicolumn{2}{|c|}{ Sabit ve Trend } \\
\hline & İstatistik & Olas -değeri & İstatistik & Olas -değer \\
\hline YO & 7.4554 & 1.000 & -0.3478 & 0.364 \\
\hline \multirow{2}{*}{ Birinci Fark } & \multicolumn{2}{|c|}{ Sabit } & \multicolumn{2}{|c|}{ Sabit ve Trend } \\
\hline & İstatistik & Olas -değeri & İstatistik & Olas -değer \\
\hline $\begin{array}{c}\text { YO } \\
\mathrm{H}_{0} \text { : Birim kök vardır. } \\
\mathrm{H}_{1} \text { : Birim kök yoktur. }\end{array}$ & -6.479 & 0.000 & -4.068 & 0.000 \\
\hline
\end{tabular}

Tablo 7'deki sonuçlar incelendiğinde; YO değişkenine ilişkin serilerin seviyesinde sabit ve sabit ve trendde durağan olmadıkları, birinci dereceden farkı alındığında sabitte ve sabit ve trendde \%5 anlamlılık düzeyinde durağanlaştığ 1 yani I (1) olduğu görülmektedir. Çalışmada incelenen yıl sayısının az olması sebebiyle trendli model yerine sabit model sonuçları dikkate alınmıştır.

\section{iv) Panel Veri Modellerinin Tahmini}

Yükseköğretime katılımın istihdam üzerindeki etkisini tespit edebilmek için sabit etkiler, rassal etkiler ve havuzlanmıș modeller içerisinde hangi modelin tahminleme için kullanılacağı F testi, Breusch-Pagan LM (1980) ve Honda (1985) testleri ile tespit edilmiştir. Bu testlere ilişkin sonuçlar Tablo 8'de gösterilmektedir.

Tablo 8. Tahmin Modeli Belirleme Analiz Sonuçları

\begin{tabular}{|c|c|c|c|c|}
\hline Test & İstatistik & $\begin{array}{l}\text { Olas } \\
\text { değer. }\end{array}$ & Hipotez & Karar \\
\hline $\begin{array}{l}\text { F-grup_sabit } \\
\text { F-zaman_sabit } \\
\text { F-ikiyönlü_sabit }\end{array}$ & $\begin{array}{c}0.944 \\
9.445 \\
3.869\end{array}$ & $\begin{array}{l}0.528 \\
0.000 \\
0.000\end{array}$ & $\begin{array}{l}\mathrm{H}_{0} \text { : Kesit etkisi varken zaman } \\
\text { etkisi yoktur. } \\
\mathrm{H}_{0} \text { : Zaman etkisi varken kesit } \\
\text { etkisi yoktur. } \\
\mathrm{H}_{0} \text { : Kesit ve zaman etkisi yoktur. }\end{array}$ & $\begin{array}{c}\text { KABUL } \\
\text { RET }\end{array}$ \\
\hline $\begin{array}{l}\text { LM-grup_rassal } \\
\text { LM-zaman_rassal } \\
\text { LM-ikiyönlü__ } \\
\text { rassal }\end{array}$ & $\begin{array}{l}1.356 \\
156.1 \\
157.4\end{array}$ & $\begin{array}{l}0.244 \\
0.000 \\
0.000\end{array}$ & $\begin{array}{l}\mathrm{H}_{0} \text { : Kesit etkisi varken zaman } \\
\text { etkisi yoktur. } \\
\mathrm{H}_{0} \text { : Zaman etkisi varken kesit } \\
\text { etkisi yoktur. } \\
\mathrm{H}_{0} \text { : Kesit ve zaman etkisi yoktur. }\end{array}$ & $\begin{array}{l}\text { KABUL } \\
\text { RET } \\
\text { RET }\end{array}$ \\
\hline $\begin{array}{l}\text { Honda-grup_rassal } \\
\text { Honda-zaman_ } \\
\text { rassal } \\
\text { Honda-ikiyönlü__ } \\
\text { rassal }\end{array}$ & $\begin{array}{c}-1.164 \\
12.493 \\
8.010\end{array}$ & $\begin{array}{l}0.877 \\
0.000 \\
0.000\end{array}$ & $\begin{array}{l}\mathrm{H}_{0} \text { : Kesit etkisi varken zaman } \\
\text { etkisi yoktur. } \\
\mathrm{H}_{0} \text { : Zaman etkisi varken kesit } \\
\text { etkisi yoktur. } \\
\mathrm{H}_{0} \text { : Kesit ve zaman etkisi yoktur. }\end{array}$ & $\begin{array}{l}\text { KABUL } \\
\text { RET } \\
\text { RET }\end{array}$ \\
\hline Hausman Testi & 0.022 & 0.881 & & \\
\hline
\end{tabular}


F testi modelin sabit etkiler modeliyle mi yoksa havuzlanmış modelle mi tahmin edileceğini anlamak için kullanılmaktadır. F testi sonuçları incelendiğinde; olasılık değeri kritik değerin altında olduğu için havuzlanmış model yerine sabit ekiler modelinin kullanılması daha güvenilir sonuçlar elde edebilmek için gereklidir. Yanı sıra grup ve zaman etkilerinin belirlendiği test sonuçları incelendiğinde modelde zaman etkisinin söz konusu olduğu söylenebilmektedir. Modelin tahmini için havuzlanmış model ile rassal etkiler modelinden hangisinin etkin olduğunun tespiti Breusch-Pagan LM (1980) ve Honda (1985) testleri ile yapılabilmektedir. Her iki test sonucuna göre; rassal etkiler modeli havuzlanmış modelden daha etkin sonuçlar vermekte ve modelde zaman etkisi varken kesit etkisinin olmadığ bilgisine ulaşılmaktadır.

Hausman testi, tahmin modelinin belirlenmesinde değil model belirlendikten sonra hangi tahmincinin kullanımının daha etkin olacağının tespiti esnasında kullanılmaktadır. Bu test, sabit etkiler modelinin tahmincisi tutarlıyken rassal etkiler modelinin tahmincisinin tutarlı olup olmadığını tespit etmek için yararlanılan bir testtir (Erlat, 2015: 24). Yani Hausman testi temelde; sabit etkiler modeli tahmincisi olan grup içi tahmincisi (within estimator) ile rassal etkiler modeli tahmincileri Tahmin Edilen Genelleştirilmiş En Küçük Kareler (EGLS) ve Uygulanabilir Genelleştirilmiş En Küçük Kareler (FGLS) arasında bir tercih yapılabilmesini sağlamaktadır (Topaloğlu, 2018). Hausman test istatistik değeri kritik değerden küçük olduğunda $\mathrm{H}_{0}$ hipotezi reddedilmektedir. Bu durumun gerçekleşmesi EGLS ve FGLS tahmincilerinin tutarsız olduğu anlamına gelmektedir. Test sonuçları incelendiğinde, Hausman testi sonucunda; olasılık değerinin kritik değerden büyük olduğu ve $\mathrm{H}_{0}$ hipotezinin reddedilemediği görülmektedir. Yani rassal etkiler modeli çalışılacaksa EGLS veya FGLS ile tahminleme yapılması gerekmektedir.

Çalışmada incelenen dönem ve ülkeler göz önünde bulundurulduğunda, veri setinin rastgele değil belirli bir grup ve belirli bir dönem için olduğu görülmektedir. Model tahminlemesinin nasıl yapılması gerektiğine ilişkin analiz sonuçları doğrultusunda çalışmada, sabit etkiler modeline dayanılarak en küçük kareler yöntemi (grup içi tahmincisi) kullanılarak tahminleme yapılmıştır.

\section{v) Değişen Varyans ve Otokorelasyonun Test Edilmesi}

Değişen varyans, hata terimlerinin varyanslarının her bir kesit için farklı olması durumudur. Otokorelasyon varsayımı ise, hata teriminin birbirini takip eden değerleri arasındaki ilişkiyi göstermektedir. Birim değerlerinin birbirinden bağımsız olmaması durumu panel veri analizinde sapmalara ve tutarsızlıklara yol açabilmektedir (Topaloğlu, 2018).

Çalışma kapsamında değişen varyans varsayımı, Breusch-Pagan-Godfrey Heteroscedasticity LM testi ile incelenirken; otokorelasyon varsayımı ise, Baltagi ve Li (1991) ve Born ve Breitung (2016) testleri ile incelenmiştir. Sabit etkiler modeline dayanılarak hesaplanan değişen varyans ve otokorelasyon istatistikleri Tablo 9'da gösterilmektedir.

Sabit etkiler modeli için hesaplanmış olan değişen varyans ve otokorelasyon sonuçlarına bakıldığında; Breusch-Pagan-Godfrey LM olasılık değerinin kritik değerden yani 0.05'ten küçük olduğu tespit edilmiş ve $\mathrm{H}_{0}$ hipotezi reddedilmiştir. Yani panelde değişen varyans problemi söz konusudur. Otokorelasyon sonuçlarında ise; Baltagi ve Li (1991) LM ve Born ve Breitung (2016) LM testlerinin olasılık değerleri 0.05 'ten küçüktür. Yani $\mathrm{H}_{0}$ hipotezi reddedilmekte ve panelde otokorelasyon problemi söz konusudur denilebilmektedir. 
Eğitim-İstihdam ve Eğitim-Gelir Etkinliği: Yükseköğretime Katılımın OECD Ülkeleri Bazında Panel Veri Analizi

Tablo 9. Sabit Etkiler Modeli İçin Değişen Varyans ve Otokorelasyon Test Sonuçları

\begin{tabular}{lll}
\hline \multicolumn{3}{c}{ Değişen Varyans } \\
\hline Breusch-Pagan-Godfrey LMh_sabit & 128.871 & 0.000000 \\
\hline $\mathrm{H}_{0}$ : Değişen varyans yoktur. & & \\
$\mathrm{H}_{1}$ : Değişen varyans vardır. & & \\
\hline \multicolumn{3}{c}{ Otokorelasyon } \\
\hline Baltagi ve Li (1991) LMp-istatistiği & 40.821 & 0.000000 \\
\hline $\mathrm{H}_{0}:$ Otokorelasyon yoktur. & & \\
$\mathrm{H}_{1}$ : Otokorelasyon vardır. & 62.646 & 0.000000 \\
\hline Born ve Breitung (2016) LMp*- istatistiği & \\
\hline $\mathrm{H}_{0}:$ Otokorelasyon yoktur. & & \\
$\mathrm{H}_{1}$ : Otokorelasyon vardır. & & \\
\hline \hline
\end{tabular}

\section{vi) Tahmin Sonuçları}

Çalışmanın bu bölümünde bağımlı ve açıklayıcı değişken arasında istatistiksel olarak anlamlı bir ilişkinin olup olmadığ 1 ve ilişki varsa bu ilişkinin yönünü tespit etmek amaçlanmıştır. Çalışmada tahmin edilecek modelde değişen varyans ve otokorelasyon sorunu olduğu belirlenmiştir. Dolayısıyla çalışmada bu sorunları dikkate alan ve çözen Beck ve Katz (1995) tarafından geliştirilen Period SUR (PCSE) yöntemi ile panel standart hatalarının düzeltilmesi yoluyla tahminleme gerçekleştirilmiştir. Tahmin sonuçları Tablo 10'da gösterilmektedir.

Tablo 10. Model Tahmin Sonuçları

\begin{tabular}{|c|c|c|c|c|}
\hline Bağımlı Değişken & & \multicolumn{2}{|c|}{ Yöntem } & Örneklem \\
\hline İST & & $\begin{array}{l}\text { En Küçük Karel } \\
\text { Period SUR (P } \\
\text { Hatalar ve } \\
\text { düzeltilmemiş) }\end{array}$ & $\begin{array}{l}\text { Yöntemi } \\
\text { SE) Panel Standart } \\
\text { Kovaryans (d.f. }\end{array}$ & 2005-2016 \\
\hline $\begin{array}{l}\text { Açıklayıcı } \\
\text { Değişken }\end{array}$ & Katsayı & Standart Hata & t-istatistiği & Olasılık \\
\hline YO & 0.114972 & 0.059048 & 1.947082 & 0.0529 \\
\hline C & -0.031551 & 0.084353 & -0.374037 & 0.7088 \\
\hline \multicolumn{5}{|c|}{ Ăğırlıklandırılmış İstatistikler } \\
\hline R-kare & \multicolumn{2}{|c|}{$0.314326 \quad$ Ort. I } & ğ. var & 0.062773 \\
\hline Düz. R-kare & \multicolumn{2}{|c|}{0.278064} & S.D. Bağ var & 1.269692 \\
\hline S.E. of reg. & \multicolumn{2}{|c|}{1.078817} & AIC & 3.042609 \\
\hline Öz. Kare. resid & \multicolumn{2}{|c|}{242.0800} & & 3.227716 \\
\hline Log like. & \multicolumn{2}{|c|}{-322.6870} & & 3.117360 \\
\hline F-istatistik & \multicolumn{2}{|c|}{8.668277} & & \\
\hline Olas(F- istatistik) & \multicolumn{2}{|c|}{0.000000} & & \\
\hline
\end{tabular}

Tablo 10'da yükseköğretime katılımın istihdam üzerindeki etkisinin tespit edilebilmesi için oluşturulan modelin tahmin sonuçları yer almaktadır. Analiz sonuçları incelendiğinde; modelin anlamlılığını gösteren F istatistik değerinin anlamlı olduğu ve açıklayıcı değişkenin bağımlı değişkende yaşanan değişimin \%31'ini $\left(\mathrm{R}^{2}\right)$ açıkladığı tespit edilmiştir. Modelde yükseköğretime katılım ile istihdam oranı arasında \%10 anlamlılık düzeyinde istatistiksel olarak anlamlı sonuçlara ulaşılmıştır. Yükseköğretime katılımda yaşanan 1 birimlik değişim istihdam oranında yaklaşık 0.11 birimlik bir artışa yol açmaktadır.

\section{C- Model 2 İçin Analiz Sonuçları}

Çalışmanın bu bölümünde yükseköğretime katılımla ilişkisi kurulabilecek bir diğer değişken olan çalışanların gayrisafi yurtiçi hasıladan aldıkları pay ile yükseköğretime katılım oranı 
arasındaki ilişkiyi belirlemek için kurulan ikinci modele ilişkin analizlere ve elde edilen bulgulara yer verilmektedir. Bu kısımda ilk olarak yatay kesit bağımlılığı ve homojenlik sınaması yapılmış, sonrasında sırasıyla birim kök testleri, tahmin modelini belirlemek için $\mathrm{F}$ Testi, değişen varyans ve otokorelasyon sınaması yapılmış son olarak da modele ilişkin tahmin sonuçlarına yer verilmiştir.

Tablo 11. Yatay Kesit Bă̆ımlılı̆̆ı Test Sonuçları

\begin{tabular}{|c|c|c|c|c|c|c|c|c|}
\hline \multirow{2}{*}{$\begin{array}{c}\text { Değişke } \\
\text { n }\end{array}$} & \multicolumn{2}{|c|}{$\begin{array}{c}\text { LM } \\
\text { (Breusch; Pagan, } \\
\text { 1980) }\end{array}$} & \multicolumn{2}{|c|}{$\begin{array}{c}\text { CDlm } \\
\text { (Pesaran, 2004) }\end{array}$} & \multicolumn{2}{|c|}{$\begin{array}{c}\text { CD } \\
\text { (Pesaran, 2004) }\end{array}$} & \multicolumn{2}{|c|}{$\begin{array}{c}\text { LMadj } \\
\text { (PUY, 2008) }\end{array}$} \\
\hline & $\begin{array}{c}\text { İstatisti } \\
\mathbf{k}\end{array}$ & $\begin{array}{c}\text { Olasılı } \\
\mathbf{k}\end{array}$ & $\begin{array}{c}\text { İstatisti } \\
\mathbf{k}\end{array}$ & $\begin{array}{c}\text { Olasilı } \\
\mathbf{k}\end{array}$ & $\begin{array}{c}\text { İstatisti } \\
\mathbf{k}\end{array}$ & $\begin{array}{c}\text { Olasilı } \\
\mathbf{k}\end{array}$ & $\begin{array}{c}\text { İstatisti } \\
\mathbf{k}\end{array}$ & $\begin{array}{c}\text { Olasilı } \\
\mathbf{k}\end{array}$ \\
\hline Panel & 724.101 & 0.000 & 27.399 & 0.000 & 14.711 & 0.000 & 93.431 & 0.000 \\
\hline GDP & 397.157 & 0.000 & 10.627 & 0.000 & 3.540 & 0.000 & 11.190 & 0.000 \\
\hline YO & 412.816 & 0.000 & 11.430 & 0.000 & -0.635 & 0.263 & 20.837 & 0.000 \\
\hline
\end{tabular}

Tablo 11'deki sonuçlar incelenirken; panel ve değişken bazında yatay kesit bağımlılığının belirlenmesinde çalışmada kesit boyutu zaman boyutundan büyük olduğu için (N>T) Pesaran CD (2004) test sonuçları dikkate alınmıştır. Analiz sonucunda, panel bazında olasılık değerinin kritik değer olan 0.05 'ten küçük olduğu ve $\mathrm{H}_{0}$ hipotezinin reddedildiği görülmekte ve panel bazında yatay kesit bağımlılığı olduğu sonucuna varılabilmektedir. Bağımlı değişken olan GDP değişkeninin olasılık değeri 0.05 'ten küçük olduğu için $\mathrm{H}_{0}$ hipotezi reddedilmiştir, yani GDP değişkeni için yatay kesit bağımlılığı söz konusudur. Açıklayıcı değişken olan YO değişkeninin olasılık değeri 0.05 'ten büyük olduğu için $\mathrm{H}_{0}$ reddedilememiştir, yatay kesit bağımlılığı yoktur. GDP değişkeninde yatay kesit bağımlılığı söz konusu olduğu için bu değişken için durağanlık sınaması gerçekleştirilirken yatay kesit bağımlılığını dikkate alan ikinci nesil birim kök testleri kullanılmıştır.

Tablo 12. Pesaran ve Yamagata(2008) Homojenite Test Sonuçları

\begin{tabular}{lcccc}
\hline & Delta_tilde & $\begin{array}{c}\text { Olasılık } \\
\text { Değeri }\end{array}$ & Düzeltilmiş_Delta_tilde & $\begin{array}{c}\text { Olasılık } \\
\text { Değeri }\end{array}$ \\
\hline Panel $(\boldsymbol{\alpha})$ & 1.645 & 0.050 & 1.900 & 0.029 \\
\hline GDP & 2.192 & 0.014 & 2.531 & 0.006 \\
\hline YO & 3.786 & 0.000 & 4.372 & 0.000 \\
\hline
\end{tabular}

$\mathrm{H}_{0}$ : Homojenlik vardır.

$\mathrm{H}_{1}$ : Homojenlik yoktur.

Pesaran ve Yamagata (2008) Homojenite test sonuçları panel bazında değerlendirildiğinde; modele ait delta ve düzeltilmiş delta olasılık değerleri 0.05 'ten küçük olduğu için panel bazında homojenlik olduğunu savunan $\mathrm{H}_{0}$ hipotezi reddedilmektedir. Yani panel bazında heterojenlik söz konusudur. GDP ve YO değişkenleri bazında Homojenite Test sonuçları incelendiğinde; GDP değişkeninin delta olasılık değeri ve düzeltilmiş delta değeri 0.05 'ten küçük olduğu için GDP değişkeni için $\mathrm{H}_{0}$ reddedilmiş olup homojenlik yoktur denilebilmektedir. YO değişkeni için, delta olasılık değeri ve düzeltilmiş delta olasılık değeri 0.05 anlamlılık düzeyinden küçük olduğundan dolayı bu değişken için de $\mathrm{H}_{0}$ hipotezi reddedilmiştir. Dolayısıyla GDP ve YO değişkenleri için heterojenlik söz konusudur. 
Tablo 13. Smith vd. (2004) Birim Kök Testi Sonuçları

\begin{tabular}{|c|c|c|c|c|}
\hline \multirow[t]{2}{*}{ Seviye } & \multicolumn{2}{|c|}{ Sabit } & \multicolumn{2}{|c|}{ Sabit ve Trend } \\
\hline & İstatistik & Olas-değeri & İstatistik & Olas -değeri \\
\hline GDP & -1.447 & 0.490 & -2.065 & 0.580 \\
\hline \multirow[t]{2}{*}{ Birinci Fark } & \multicolumn{2}{|c|}{ Sabit } & \multicolumn{2}{|c|}{ Sabit ve Trend } \\
\hline & İstatistik & Olas -değeri & İstatistik & Olas -değeri \\
\hline GDP & -3.127 & 0.000 & -3.509 & 0.050 \\
\hline $\begin{array}{l}\mathrm{H}_{0} \text { : Birim kök vardır. } \\
\mathrm{H}_{1} \text { : Birim kök yoktur. }\end{array}$ & & & & \\
\hline
\end{tabular}

Tablo 13'teki sonuçlar incelendiğinde; GDP değişkenine ilişkin serilerin seviyesinde sabit ve sabit ve trendde durağan olmadıkları, birinci dereceden farkı alındığında sabitte \%5 anlamlılık düzeyinde durağan, sabit ve trendde de $\% 5$ anlamlılık düzeyinde durağanlaştığı görülmektedir. Çalışmada incelenen yıl sayısının az olması sebebiyle trendli model yerine sabit model sonuçları dikkate alınmıştır.

Tablo 14. IPS Panel Birim Kök Test Sonuçları

\begin{tabular}{|c|c|c|c|c|}
\hline \multirow{2}{*}{ Seviye } & \multicolumn{2}{|c|}{ Sabit } & \multicolumn{2}{|c|}{ Sabit ve Trend } \\
\hline & İstatistik & Olas-değeri & İstatistik & Olas -değer \\
\hline YO & 7.4554 & 1.000 & -0.3478 & 0.364 \\
\hline Birinci Frrk & \multicolumn{2}{|c|}{ Sabit } & \multicolumn{2}{|c|}{ Sabit ve Trend } \\
\hline 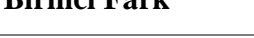 & İstatistik & Olas -değeri & İstatistik & Olas -değeri \\
\hline YO & -6.479 & 0.000 & -4.068 & 0.000 \\
\hline $\begin{array}{l}\mathrm{H}_{0} \text { : Birim kök vardır. } \\
\mathrm{H}_{1} \text { : Birim kök yoktur. }\end{array}$ & & & & \\
\hline
\end{tabular}

Tablo 14'deki sonuçlar incelendiğinde; YO değişkenine ilişkin serilerin seviyesinde sabit ve sabit ve trendde durağan olmadıkları, birinci dereceden farkı alındığında sabitte ve sabit ve trendde $\% 5$ anlamlılık düzeyinde durağanlaştığı yani I (1) olduğu görülmektedir. Çalışmada incelenen yıl sayısının az olması sebebiyle trendli model yerine sabit model sonuçları dikkate alınmıştır.

Tablo 15. Tahmin Modeli Belirleme Analiz Sonuçları

\begin{tabular}{|c|c|c|c|c|}
\hline Test & İstatistik & $\begin{array}{l}\text { Olas- } \\
\text { değer. }\end{array}$ & Hipotez & Karar \\
\hline $\begin{array}{l}\text { F-grup_sabit } \\
\text { F-zaman_sabit } \\
\text { F-ikiyönlü_sabit }\end{array}$ & $\begin{array}{l}611.35 \\
6.7947 \\
389.81\end{array}$ & $\begin{array}{l}0.000 \\
0.000 \\
0.000\end{array}$ & $\begin{array}{l}\mathrm{H}_{0} \text { : Kesit etkisi varken zaman } \\
\text { etkisi yoktur. } \\
\mathrm{H}_{0} \text { : Zaman etkisi varken kesit } \\
\text { etkisi yoktur. } \\
\mathrm{H}_{0} \text { : Kesit ve zaman etkisi yoktur. }\end{array}$ & $\begin{array}{l}\text { RET } \\
\text { RET } \\
\text { RET }\end{array}$ \\
\hline $\begin{array}{l}\text { LM-grup_rassal } \\
\text { LM-zaman_rassal } \\
\text { LM-ikiyönlü_rassal }\end{array}$ & $\begin{array}{l}1226.9 \\
4.8407 \\
1231.7\end{array}$ & $\begin{array}{l}0.000 \\
0.027 \\
0.000\end{array}$ & $\begin{array}{l}\mathrm{H}_{0} \text { : Kesit etkisi varken zaman } \\
\text { etkisi yoktur. } \\
\mathrm{H}_{0} \text { : Zaman etkisi varken kesit } \\
\text { etkisi yoktur. } \\
\mathrm{H}_{0} \text { : Kesit ve zaman etkisi yoktur. }\end{array}$ & $\begin{array}{l}\text { RET } \\
\text { RET } \\
\text { RET }\end{array}$ \\
\hline $\begin{array}{l}\text { Honda-grup_rassal } \\
\text { Honda-zaman_- } \\
\text { rassal } \\
\text { Honda-ikiyönlü__ } \\
\text { rassal } \\
\text { Hausman Testi }\end{array}$ & $\begin{array}{l}35.027 \\
-2.2001 \\
23.212\end{array}$ & $\begin{array}{l}0.000 \\
0.986 \\
0.000\end{array}$ & $\begin{array}{l}\mathrm{H}_{0} \text { : Kesit etkisi varken zaman } \\
\text { etkisi yoktur. } \\
\mathrm{H}_{0} \text { : Zaman etkisi varken kesit } \\
\text { etkisi yoktur. } \\
\mathrm{H}_{0} \text { : Kesit ve zaman etkisi yoktur. }\end{array}$ & $\begin{array}{c}\text { RET } \\
\text { KABUL }\end{array}$ \\
\hline
\end{tabular}


Test sonuçları incelendiğinde, Hausman testi sonucunda; olasılık değerinin kritik değerden büyük olduğu ve $\mathrm{H}_{0}$ hipotezinin reddedilemediği görülmektedir. Yani rassal etkiler modeli çalışılacaksa EGLS veya FGLS ile tahminleme yapılması gerekmektedir. Model tahminlemesinin nasıl yapılması gerektiğine ilişkin analiz sonuçları doğrultusunda çalışmada, sabit etkiler modeline dayanılarak en küçük kareler yöntemi grup içi tahmincisi (within estimator) kullanılarak tahminleme yapılmıştır.

Model 2'de de değişen varyans ve otokorelasyon varsayımları Model 1'de açıklandı̆̆ 1 şekilde gerçekleştirilmiştir. Model 2 için değişen varyans ve otokorelasyon test istatistikleri Tablo 16'da gösterilmektedir.

Tablo 16. Sabit Etkiler Modeli İçin Değişen Varyans ve Otokorelasyon Test Sonuçları

\begin{tabular}{|c|c|c|}
\hline \multicolumn{3}{|c|}{ Değişen Varyans } \\
\hline \multirow{2}{*}{ Breusch-Pagan-Godfrey LMh_sabit } & İstatistik & Olas-değeri \\
\hline & 433.131 & 0.000000 \\
\hline \multicolumn{3}{|l|}{$\begin{array}{l}\mathrm{H}_{0} \text { : Değişen varyans yoktur. } \\
\mathrm{H}_{1} \text { : Değişen varyans vardır. }\end{array}$} \\
\hline \multicolumn{3}{|c|}{ Otokorelasyon } \\
\hline \multirow{2}{*}{ Baltagi ve Li (1991) LMp- sabit } & İstatistik & Olas-değeri \\
\hline & 97.246 & 0.000000 \\
\hline \multicolumn{3}{|l|}{$\begin{array}{l}\mathrm{H}_{0} \text { : Otokorelasyon yoktur. } \\
\mathrm{H}_{1} \text { : Otokorelasyon vardır. }\end{array}$} \\
\hline \multirow{2}{*}{ Born ve Breitung (2016) LMp*- sabit } & İstatistik & Olas-değeri \\
\hline & 128.655 & 0.000000 \\
\hline $\begin{array}{l}\mathrm{H}_{0} \text { : Otokorelasyon yoktur. } \\
\mathrm{H}_{1} \text { : Otokorelasyon vardir. }\end{array}$ & & \\
\hline
\end{tabular}

Sabit etkiler modeli için hesaplanmış olan değişen varyans ve otokorelasyon test sonuçları incelendiğinde; Breusch-Pagan-Godfrey LM olasılık değerinin 0.05'ten küçük olduğu tespit edilmiş ve $\mathrm{H}_{0}$ hipotezi reddedilmiştir. Yani panelde değişen varyans söz konusudur. Otokorelasyon test sonuçlarına bakıldığında; Baltagi ve Li (1991) LM ve Born ve Breitung (2016) LM testlerinin olasılık değerleri 0.05 'ten küçüktür. Yani $\mathrm{H}_{0}$ hipotezi reddedilmektedir ve panelde otokorelasyon sorunu söz konusudur.

Tablo 17. Model Tahmin Sonuçları

\begin{tabular}{|c|c|c|c|c|}
\hline Bağımlı Değişken & & \multicolumn{2}{|l|}{ Yöntem } & Örneklem \\
\hline GDP & & \multicolumn{2}{|c|}{$\begin{array}{l}\text { En Küçük Kareler Yöntemi } \\
\text { White Period Panel Standart Hatalar } \\
\text { ve Kovaryans (d.f. düzeltilmemiş) }\end{array}$} & 2005-2016 \\
\hline $\begin{array}{l}\text { Açıklayıcı } \\
\text { Değişken }\end{array}$ & Katsayı & Standart Hata & t-istatistiği & Olasılık \\
\hline YO & -0.001930 & 0.001131 & -1.706213 & 0.0896 \\
\hline C & 0.008446 & 0.000928 & 9.101331 & 0.0000 \\
\hline \multicolumn{5}{|c|}{ Ağırlıklandırılmış İstatistikler } \\
\hline R-kare & \multirow{2}{*}{\multicolumn{2}{|c|}{$0.381008 \quad$ Or }} & . var & 0.006863 \\
\hline Düz. R-kare & & & var & 0.025387 \\
\hline S.E. of reg. & \multicolumn{2}{|c|}{$\begin{array}{l}0.282755 \\
0.021501\end{array}$} & & -4.711541 \\
\hline Öz. Kare. resid & \multicolumn{2}{|c|}{0.087370} & & -4.233348 \\
\hline Log like. & \multicolumn{2}{|c|}{549.2695} & & -4.518434 \\
\hline F-istatistik & \multirow{2}{*}{\multicolumn{2}{|c|}{$\begin{array}{l}3.877837 \\
0.000000\end{array}$}} & & \\
\hline Olas(F- istatistik) & & & 0.000000 & \\
\hline
\end{tabular}


Tablo 17'de yükseköğretime katılımın çalışanların gayrisafi yurtiçi hasıladan aldıkları pay üzerindeki etkisinin tespit edilebilmesi için oluşturulan modelin tahmin sonuçları yer almaktadır. Analiz sonuçları incelendiğinde, F istatistik değerinin anlamlı olduğu ve açıklayıcı değişkenin bağımlı değişkende gerçekleşen değişimin \%38'ini $\left(\mathrm{R}^{2}\right)$ açıkladığı belirlenmiştir. Modelde yükseköğretime katılım ile çalışanların gayrisafi yurtiçi hasıladan aldıkları pay arasında \%10 anlamlılık düzeyinde istatistiksel olarak anlamlı sonuçlar elde edilmiştir. Yükseköğretime katılımda yaşanan 1 birimlik bir değişim çalışanların gayrisafi yurtiçi hasıladan aldıkları payda yaklaşık 0.0019 birimlik bir azalışa yol açmaktadır.

\section{SONUÇ}

Bu çalışma ile yükseköğretime katılımın istihdama ve çalışanların gayrisafi yurtiçi hasıladan aldıkları paya etkisi incelenmiştir. Analizde kullanılacak değişkenler kapsamında; açıklayıcı değişken olarak yükseköğretime katılım oranı, bağımlı değişkenler olarak da birinci model için istihdam oranı ikinci model için çalışanların gayrisafi yurtiçi hasıladan aldıkları pay seçilmiştir. Çalışmaya konu olan ülkeler ise OECD ülkelerinin 20 kurucu üyesi olarak belirlenmiş ve 2005-2016 yılları verileri analize dahil edilmiştir. Çalışma ile yükseköğretime katılımın ilk olarak istihdama etkisi sonrasında ise çalışanların gayrisafi yurtiçi hasıladan aldıkları paya etkisi panel veri analizi uygulanarak incelenmiştir.

Analiz kapsamında ilk etapta birinci model için, paneli oluşturan yatay kesitler (OECD kurucu üye ülkeleri) arasındaki bağımlılık panel ve değişken bazında Pesaran (2004) CD testleriyle incelenmiştir. Değişkenlerin katsayılarının yatay kesitler arasında değişkenlik gösterip göstermediği Pesaran ve Yamagata (2008) Homojenite Testi ile araştırılmıştır. Değişkenler için durağanlık sınaması Smith vd. (2004) Bootstrap ve IPS (2003) Panel Birim Kök testleriyle yapılmıştır. Tahmin modelinin belirlenmesi için ise, F Testi uygulanmıştır. Değişen varyans ve otokorelasyon sorununun varlığının tespiti için Sabit Etkiler Modeli İçin Değişen Varyans ve Otokorelasyon testi uygulanmış olup son adım olarak paneldeki değişen varyans ve otokorelasyon sorunlarına çözüm üreten Period SUR yöntemi kullanılarak panel standart hatalarının düzeltilmesi yoluyla tahminleme gerçekleştirilmiştir. İkinci model için, yatay kesit bağımlılığı Pesaran (2004) CD testi ile incelenmiş, sonrasında Pesaran ve Yamagata (2008) Homojenite Testi ile değişkenlerin katsayılarının yatay kesitten yatay kesite değişip değişmediği sınanmıştır. Durağanlık sınaması Smith vd. (2004) Bootstrap ve IPS (2003) Panel Birim Kök testleriyle yapılmıştır. Bu modelde de birinci modelde olduğu gibi tahmin modelinin belirlenmesi için, F Testi uygulanmış, değişen varyans ve otokorelasyon sorununun tespiti için Sabit Etkiler Modeli İçin Değişen Varyans ve Otokorelasyon testi uygulanmıştır. Son olarak paneldeki değişen varyans ve otokorelasyon sorunlarına çözüm üreten White Period yöntemi kullanılarak panel standart hatalarının düzeltilmesi yoluyla tahminleme gerçekleştirilmiştir.

Yapılan analiz sonuçlarına göre; kurulan birinci modelin \%1 anlamlılık düzeyinde anlamlı olduğu ve modelin açıklama gücünün ise yaklaşık \%31 olduğu belirlenmiştir. Analiz sonucunda, yükseköğretime katılım ile istihdam oranı arasında istatistiksel olarak anlamlı ve pozitif yönlü bir ilişki tespit edilmiştir. Sonuçlara göre; yükseköğretime katılımda meydana gelen bir birimlik artış istihdam oranında yaklaşık 0.11 birimlik bir artışa yol açmaktadır. Bu sonuç neticesinde, yükseköğretime katılımın seçilen ülkeler için 2005-2016 yılları arasında istihdam oranını artırdığg görülse de beklenen ve hedeflenen ölçüde bir artışa sebep olmadığg yargısına varılabilir. Çalışma kapsamında kurulan ikinci modelin ise, \%1 anlamlılık düzeyinde anlamlı olduğu ve modelin açıklama gücünün ise yaklaşık \%38 olduğu belirlenmiştir. Tahmin sonuçlarına göre, yükseköğretime katılım ile çalışanların gayrisafi yurtiçi hasıladan aldıkları pay arasında istatistiksel olarak anlamlı ve negatif yönlü bir ilişki olduğu gözlenmektedir. Yükseköğretime katılımda meydana gelen bir birimlik artış 
çalışanların gayrisafi yurtiçi hasıladan aldıkları payı yaklaşık 0.002 birim azaltmaktadır. Özellikle Türkiye açısından 1980 sonrası dönemde portföy yatırımlarının ve faiz ve kar getirilerinin GSYİH içindeki payının artışı ve çalışanların (Ücretli ve maaşlı) ücretlerinde meydana gelen erime neticesinde çalışanların GSYİH'dan aldıkları pay azalış göstermektedir denilebilmektedir.

Araştırmanın sonucunda elde edilen bulgulara göre, yükseköğretime katılımın istihdam ile olan ilişkisi çok güçlü değildir. Eğitim seviyesindeki artış kimi zaman işsizlik oranlarında da bir artışa neden olmaktadır. Bunun yanı sıra yükseköğretime katılımda yaşanan artışa rağmen, çalışanların GSYİH'dan aldıkları payın düşmesi de aslında emek piyasasının karşı karşıya olduğu sorunların başında gelmektedir. Ülke ekonomilerinin yapısal sorunları ve yükseköğretim sisteminin, çalışma ilişkileri sistemine uygun olmayan yapısı nedeniyle bu durumun ortaya çıktığı düşünülmektedir. Ayrıca zaman içerisinde yükseköğretim kurumlarının sayısında yaşanan artışla beraber yükseköğretim mezunu kişi sayısının artması işgücü arzında bir artışa sebep olmakta, oluşan bu arz fazlası ücretlerde azalmaya sebep olmaktadır. Ücretlerde yaşanan bu azalışın yanında resmi istatistik kurumlarının yayınladığı verilerde de görülebileceği üzere sermayenin milli gelirden aldığı payın artması da çalışanların GSYİH'dan aldıkları payın azalması sonucunu doğurmaktadır. Özetle yükseköğretime katılan kişi sayısında yaşanan artış, eğitim sisteminin emek piyasasının ihtiyaçlarını karşılayacak nitelikte olamayışı yükseköğretimin etkinliğini azaltıcı yönde etkilemektedir. Bu noktadan hareketle, eğitim sisteminin özellikle de mesleki eğitim sisteminin yükseköğretim ile birlikte, emek piyasasının değişen koşulları göz önünde bulundurularak yeniden yapılandırılması gerekmektedir.

\section{Kaynakça}

Abdioğlu, Z. ve Albayrak, N. (2018). Türkiye'de Yükseköğretimin Sektörel Büyümeye Etkisi. Uluslararasl Iktisadi ve İdari Incelemeler Dergisi. (Prof. Dr. Harun Terzi Özel Saylsi).127-140.

Akgül, I. ve Koç, S. Ö. (2011). Türkiye Cumhuriyeti Tarihinde Eğitim ve Büyüme İlişkisi: Eşik Otoregresif Yaklaşım. Trakya Üniversitesi Sosyal Bilimler Dergisi. 13(2). 136.

Akınc1, A. (2017). Türkiye'de Eğitim Harcamalarının Ekonomik Büyüme Üzerindeki Etkisi. Maliye Dergisi. (173). 387-397.

Baltagi, B. ve Li, Q. (1991). A Joint Test for Serial Correlation and Random Individual Effects. Statistics and Probability Letters. 11. 277-280.

Beck, N. ve Katz, J. (1995). What To Do (And Not To Do) with Time-Series Cross-Section Data. American Political Science Review. 89(3). 634-647.

Blankenau, W. F., Simpson, N. B. ve Tomljanovich, M. (2007). Public Education Expenditures, Taxation and Growth: Linking Data To Theory. American Economic Association. 97(2). 393-397.
Born, B. ve Breitung, J. (2016). Testing for Serial Correlation in Fixed-Effects Panel Data Models. Econometric Reviews. 35(7). 12901316.

Brauns, H., Gangl, M. ve Scherer, S. (1999). Education and Unemployment: Patterns of Labour Market Entry in France, the United Kingdom and West Germany, Mannheim Centre for European Social Research (MZES) University of Mannheim. P.O. Box 103462. D$68131 \quad$ Mannheim. Germany. [http://edoc.vifapol.de/opus/volltexte/2014/510 1/pdf/wp6.pdf]. (Erişim: 17 Kasım 2020).

Breusch, T. ve Pagan, A. (1980). The Lagrange Multiplier Test and Its Applications to Model Specification in Econometrics. Review of Econometric Studies. 47(1). 239-253.

Çoban, O. (2004). Beşeri Sermayenin İktisadi Büyüme Üzerine Etkisi: Türkiye Örneği. İstanbul Üniversitesi, Siyasal Bilgiler Fakültesi Dergisi. No. 30. 131-142.

Erdem, E. ve Tuğcu, C. T. (2012). Higher Education and Unemployment: A Cointegration and Causality Analysis of the Case of Turkey. European Journal of Education. 47(2). 299-309. 
Eriçok, R. E. ve Yılancı, V. (2013). Eğitim Harcamaları ve Ekonomik Büyüme İlişkisi: Sınır Testi Yaklaşımı. Bilgi Ekonomisi ve Yönetimi Dergisi. 8(1). 87-101.

Erlat, H. (2015). Panel Data: A Selective Survey. Ankara: Department of Economics Middle East Technical University.

Ford, M. (2018). Robotların Yükselişi Yapay Zeka ve İssiz Bir Gelecek Tehlikesi. (C. Duran, Çev.) İstanbul: Kronik Kitap.

Gölpek, F. (2011). Yükseköğretimin Getirileri ve Etkinlik Sorunu. Atatürk Üniversitesi İktisadi ve İdari Bilimler Dergisi. 25(3-4). 77-95.

Gujarati, D. N. (2003). Basic Econometric: International Edition. Singapore: McGraw-Hill.

Honda, Y. (1985). Testing the Error Components Model with Non-Normal Disturbances. Review of Economic Studies. (52). 681-690.

Hunady, J. ve Pisar, P. (2016). Higher Education and Regional Unemployment: Is There any Relation Between Them? Conference Paper. 157-167.

[https://www.researchgate.net/publication/3106 05337]. (Erişim: 17 Kasım 2020).

Im, K., Pesaran, H. ve Shin, Y. (2003). Testing for Unit Roots in Heterogeneous Panels. Journal of Econometrics. (115). 53-74.

Karabarbounis, L. ve Neiman, B. (2013). The Global Decline of the Labor Share. National Bureau of Economic Research. No. W19136.

Karagül, M. (2003). Beşeri Sermayenin Ekonomik Büyümeyle İlişkisi ve Etkin Kullanımı. Akdeniz Üniversitesi İktisadi İdari Bilimler Fakültesi Dergisi. (5). 79-90.

Karataş, M. ve Çankaya, E. (2010). İktisadi Kalkınma Sürecinde Beşeri Sermayeye İlişkin Bir İnceleme. M. Akif Ersoy Üniversitesi Sosyal BilimlerEnstitüsü Dergisi. (3). 29-55.

Karataş, M. ve Çankaya, E. (2011). Türkiye'de Beşeri Sermaye ve Ekonomik Büyüme İlişkisinin Analizi. Yönetim ve Ekonomi Dergisi. 18(1). 105-124.

Lavrinovicha, I., Lavrinenko, O. ve TeivansTreinovskis, J. (2015). Influence of Education on Unemployment Rate and Incomes of Residents. Procedia-Social and Behavioral Sciences. (174). 38243831.
Masatçı, H. S. (2005). Türkiye'de Beşeri Sermaye ve İktisadi Büyüme İlişkisi: KoEntegrasyon Analizi. Atatürk Üniversitesi İktisadi İdari Bilimler Fakültesi Dergisi. 19(2). 49-58.

Nunez, I. ve Livanos, I. (2010). Higher Education and Unemployment in Europe: An Analysis of the Academic Subject and National Effects. Higher Education. (59). 475-487.

Özsoy, C. (2009). Türkiye'de Eğitim ve İktisadi Büyüme Arasındaki İlişsinin VAR Modeli ile Analizi. Bilgi Ekonomisi ve Yönetimi Dergisi. 4(1). 71-83.

Özyakışır, D. (2011). Beşeri Sermayenin Ekonomik Kalkınma Sürecindeki Rolü: Teorik Bir Değerlendirme. Girişimcilik ve Kalkınma Dergisi. 6(1). 46-71.

Pesaran, M. H. (2004). General Diagnostic Tests for Cross Section Dependence in Panels. Cambridge Working Papers in Economics Working Paper. (435). 3-11.

Pesaran, H. ve Yamagata, T. (2008). Testing Slope Homogeneity in Large Panels. Journal of Econometrics. (142). 50-93.

Riasat, S., Atif, R. M. ve Zaman, K. (2011). Measuring The Impact of Educational Expenditures on Economic Growth: Evidence from Pakistan. Educational Research. 2(13).1839-1846.

Riddell, W. C. ve Song, X. (2011). The Impact of Education on Unemployment Incidence and Re Employment Success: Evidence from the US Labour Market. Labour Economics. 18(4). 453463.

Smith, V., Leybourne, S., Kim, T. H. ve Newbold, P. (2004). More Powerful Panel Data Unit Root Tests with an Application to Mean Reversion in Real Exchange Rates. Journal of Applied Econometrics. (19). 147-170.

Şimşek, M. ve Kadılar, C. (2010). Türkiye'de Beşeri Sermaye, İhracat ve Ekonomik Büyüme Arasındaki İlişkinin Nedensellik Analizi. Cumhuriyet Üniversitesi Iktisadi ve İdari Bilimler Dergisi. 11(1). 115-140.

Topaloğlu, E. E. (2018). Bankalarda Finansal Kurılganlığ Etkileyen Faktörlerin Panel Veri Analizi ile Belirlenmesi. Eskişehir Osmangazi Üniversitesi İktisadi İdari Bilimler Faküültesi Dergisi. 13(1). 15-38. 
